Georgia State University

ScholarWorks @ Georgia State University

\title{
8-4-2014
}

\section{Family Welfare and the Great Recession}

Julie L. Hotchkiss

Georgia State University, julie.I.hotchkiss@atl.frb.org

Robert E. Moore

Georgia State University, rmoore@gsu.edu

Fernando Rios-Avila

Levy Economics Institute of Bard College, friosavi@levy.org

Follow this and additional works at: https://scholarworks.gsu.edu/uwrg_workingpapers

\section{Recommended Citation}

Hotchkiss, Julie L.; Moore, Robert E.; and Rios-Avila, Fernando, "Family Welfare and the Great Recession" (2014). UWRG Working Papers. 81.

https://scholarworks.gsu.edu/uwrg_workingpapers/81

This Article is brought to you for free and open access by the Usery Workplace Research Group at ScholarWorks @ Georgia State University. It has been accepted for inclusion in UWRG Working Papers by an authorized administrator of ScholarWorks @ Georgia State University. For more information, please contact scholarworks@gsu.edu. 


\section{W. J. Usery Workplace Research Group Paper Series}

Working Paper 2014-8-4

August 2014

\section{Family Welfare and the Great Recession}

Julie L. Hotchkiss

Federal Reserve Bank of Atlanta

Georgia State University

Robert E. Moore

Georgia State University

Fernando Rios-Avila

Levy Economics Institute of Bard College 


\title{
Family Welfare and the Great Recession
}

Julie L. Hotchkiss ${ }^{*}$

Federal Reserve Bank of Atlanta and

Georgia State University

Julie.L.Hotchkiss@atl.frb.org

404-498-8198
Robert E. Moore

Georgia State University

rmoore@gsu.edu

404-413-0056
Fernando Rios-Avila

Levy Economics Institute of Bard College

friosavi@levy.org

845-758-7719

August 21, 2014

\begin{abstract}
The analysis in this paper provides estimates of family welfare losses generated by wage and non-labor income declines experienced across the Great Recession and by labor market constraints existing post-recession. Welfare losses are greater as families (both married and single) move up the income distribution. Total static welfare losses are estimated to amount to roughly \$190 billion, comparing family welfare between 2007 and 2011.
\end{abstract}

Key Words: Family welfare, joint labor supply, microsimulation, constrained hours

JEL Codes: $\quad$ I30 Welfare, Well-being, and Poverty

J22 Time Allocation and Labor Supply

D19 Household Behavior and Family Economics

E32 Business Fluctuations, Cycles

\footnotetext{
* Corresponding author. The views expressed here are not necessarily those of the Federal Reserve Bank of Atlanta, or the Federal Reserve System. This paper has benefited from comments from participants at the FRS Meeting on Applied Microeconomics and the Western Economic Association.
} 


\section{Family Welfare and the Great Recession}

\section{$\underline{\text { I. Introduction and Background }}$}

Analyses of the impact of the Great Recession on families have taken many forms. Morgan et al. (2012) find little evidence that the Great Recession affected fertility rates, cohabitation, or divorce, although they do find an increase in the proportion of young adults living with their parents. A more dramatic assessment can be found in Warner (2010:2):

"The poor are getting poorer, and the rich, despite stock-market setbacks, are still comparatively rich. The most devastating losses in household wealth over the past two years have been suffered by the middle class. And families are fraying at the seams."

There is no question that economic statistics, such as net family wealth (Lerman 2012), foregone consumption (Lansing 2011), underemployment (Sum and Khatiwada 2010), and long-term unemployment (Kroft, et al 2013) paint of picture of families worse off after the recession than before. The purpose of this paper is to quantify the overall welfare impact of the Great Recession experienced by families across the income distribution. A particular focus will be on the implications for welfare of the decline on real wages and non-labor income, and the constrained optimization implied by the notion of underemployment.

The microsimulation methodology employed by Hotchkiss, Moore, and Rios-Avila (2012) will be used to estimate parameters of a joint labor supply model within the context of a family utility framework for couple households, while a similar extension will be applied to single headed households. ${ }^{1}$ For the purposes of the question posed here, the estimated parameters from the family utility model will be used to simulate the impact on family welfare of varying labor market conditions. The goal of the static analysis in this paper will be to provide a

\footnotetext{
${ }^{1}$ Microsimulation is a popular methodology for assessing the impact of tax policy changes (for example, see Fiorio 2008, Blundell et al. 2000, Bahl et al. 1993, and Blundell 1992).
} 
quantitative value of welfare against which to compare the cost of policies under consideration to alleviate suboptimal labor market outcomes. In this paper, a family's welfare is measured directly as the dollar equivalent utility the family experiences under alternative labor market scenarios. This paper does not to derive an optimal policy that would return families to their prerecession, or even unconstrained post-recession, utility levels, but, rather, the goal of this analysis is to quantify the welfare loss incurred by different types of families along the income distribution across the Great Recession.

\section{Methodology}

\section{A. Family Utility Framework}

Family labor supply decisions are modeled here in a neoclassical joint utility framework. This model can be thought of as a reduced-form specification of family decision making. The model yields a clear-cut expression of family welfare that allows for cross wage effects on each member's labor supply decision. The assumption of joint family utility (or, "collective" utility) is often rejected in favor of a bargaining structure to household decisions making (for example, see Apps and Rees, 2009, McElroy, 1990). However there is evidence that the choice of structure for household decision making has very little implication for conclusions in microsimulation exercises (see Bargain and Moreau, 2003). In addition, Blundell et al. (2007) find that both collective and bargaining models are consistent with their household labor supply model estimated in the U.K. The joint utility framework is used here in order to evaluate welfare changes of the family (as opposed to evaluating the utility of individuals).

Within the framework of the neoclassical family labor supply model, a family maximizes a utility function that represents the household welfare. Assuming, for simplicity, that there are 
only two working members of the household (husband and wife), the family chooses levels of leisure for each member and a joint consumption level in order to solve the following problem: ${ }^{2}$

$$
\begin{aligned}
& \max _{\left(L_{1}, L_{2}, C\right)} U=U\left(L_{1}, L_{2}, C\right) \\
& \text { subject to } C=w_{1} h_{1}+w_{2} h_{2}+Y .
\end{aligned}
$$

Define $\mathrm{T}$ as total time available for an individual; $L_{1}=T-h_{1}$ will be referred to as the husband's leisure, and $L_{2}=T-h_{2}$ will be referred to as the wife's leisure; $h_{1}$ is the labor supply of the husband; $h_{2}$ is the labor supply of the wife; $C$ is total money income (or consumption with price equal to one); $w_{1}$ is the husband's after-tax market wage; $w_{2}$ is the wife's market wage; and $Y$ is non-labor income. Although we refer to $L_{1}$ and $L_{2}$ as the "leisure" of the husband and wife, respectively, they actually correspond to all uses of non-market time, including home production activities. $^{3}$

The solution to the maximization problem in equation (1) can be expressed in terms of the indirect utility function, which is solely a function of the wages of the husband and wife and non-labor income of the family:

$$
\begin{array}{r}
V\left(w_{1}, w_{2}, Y\right)=U\left\{\left[T-h_{1}^{*}\left(w_{1}, w_{2}, Y\right)\right],\left[T-h_{2}^{*}\left(w_{1}, w_{2}, Y\right)\right],\right. \\
\left.\left[w_{1} h_{1}^{*}\left(w_{1}, w_{2}, Y\right)+w_{2} h_{2}^{*}\left(w_{1}, w_{2}, Y\right)+Y\right]\right\},
\end{array}
$$

where $h_{1}^{*}\left(w_{1}, w_{2}, Y\right)$ and $h_{2}^{*}\left(w_{1}, w_{2}, Y\right)$ correspond to the optimal labor supply equations (desired hours) for the husband and wife, respectively. By totally differentiating the indirect utility function, we can simulate the change in welfare that derives from changes in optimal hours of

${ }^{2}$ This strategy is adapted to expand the analysis and include single headed households. Empirically, this implies setting hours and wages of the second member equal to zero, as well as constraining all utility parameters concerning the second member to be zero. In addition, sample construction excludes families with unmarried, same- or opposite-sex adults/partners. There are not enough occurances to produce reliable utility function parameters for this family type. ${ }^{3}$ Apps and Rees (2009) are highly critical of family utility models that do not include measures of household production, but even they acknowledge that not much can be done without the availability of richer data (p. 108). Since the focus of the analysis in this paper is utility at the household level, the absence of home production activities is not crucial. 
work and consumption in response to changes in wages and non-labor income (also see Apps and Rees, 2009: 263):

$$
d V=-U_{1} d h_{1}^{*}-U_{2} d h_{2}^{*}+U_{3} d C^{*},
$$

where $U_{1}$ is the family's marginal utility of the husband's leisure, $U_{2}$ is the family's marginal utility of the wife's leisure, and $U_{3}$ is the family's marginal utility of consumption. Equation (3) makes it clear that the change in welfare not only depends on the individual labor supply responses, but also on the family's marginal evaluation of a change in leisure and home income.

\section{B. Simulating the Welfare Impact of Suboptimal Outcomes}

When assessing welfare at suboptimal outcomes, we can no longer use the indirect utility function, but, rather, must use the direct utility function to calculate changes in welfare, based on the actual (rather than optimal) labor supply changes. ${ }^{4}$ One statistic often pointed to in support of the contention of suboptimal outcomes during the Great Recession is the stubbornly elevated share of the workforce that is part-time for economic reasons (i.e., have a part-time job, but would like to work full-time). We would consider these individuals to be underemployed from a utility maximizing perspective.

Generally, we will identify someone as underemployed in this analysis if the person is observed working fewer hours post-recession than his/her predicted optimum, based on prerecession preferences and post-recession wages and non-labor income. Figure 1 provides a simple illustration for an individual of the type of comparison that will be possible from the empirical analysis. The indifference curve $U_{2007}^{*}$ corresponds to this person's pre-recession optimum level of hours of work/leisure and consumption. Post-recession, if real wages and nonlabor income are lower, this person would be forced to a new optimum, $U_{2011}^{*}$, at fewer hours of

\footnotetext{
${ }^{4}$ In other words, $d U\left(L_{1}, L_{2}, C\right)=U_{1} d L_{1}+U_{2} d L_{2}+U_{3} d C^{*}=-U_{1} d h_{1}-U_{2} d h_{2}+U_{3} d C$. See Appendix A for details.
} 
work and lower consumption. If this person is further constrained in hours of work (e.g., parttime for economic reasons, or, in the extreme, unemployed), he/she ends up on the indifference curve $\widetilde{U}_{2011}$, at even fewer hours of work and lower consumption.

\section{[Figure 1 here]}

When labor markets are tight, we assume that individuals are able to choose their optimal hours of work without constraint. Or, at least there are enough wage/hours combinations of job offers that one can get close to their optimum hours for a given wage. In a weak labor market, the number of wage/hours combinations is likely significantly reduced, constraining the hours options available at a given wage. The welfare impact of this scenario is illustrated in Figure 1 as a movement from $U_{2011}^{*}$ (unconstrained hours optimization) to $\widetilde{U}_{2011}$ (with constrained hours). Empirically, in the framework of the proposed methodology, the family welfare changes described above can be calculated as: ${ }^{5}$

$$
U_{2011}^{*}-U_{2007}^{*}=-\bar{U}_{1} d h_{1}^{*}-\bar{U}_{2} d h_{2}^{*}+\bar{U}_{3} d C^{*}
$$

and

$$
\widetilde{U}_{2011}-U_{2011}^{*}=-\widetilde{U}_{1} d \widetilde{h}_{1}-\widetilde{U}_{2} d \tilde{h}_{2}+\widetilde{U}_{3} \times d \tilde{C}
$$

Details of these calculations are found in Appendix A. Note that the change in hours $\left(d h_{i}^{*}\right.$ and $d \tilde{h}_{i}$ ) take into account changes on the extensive and intensive margin of the hours worked, averaged across the population.

The actual impact on utility will depend on the relative value a family places on leisure and income. At low values of marginal utility of income or low wages, it is possible for utility to increase for a small decrease in hours of work. However, as hours of work decline further, the marginal utility of leisure gained declines while the marginal utility of income losses increases,

\footnotetext{
${ }^{5}$ Since utility is decreasing in hours of work, hours enter negatively on the right hand side of the equation.
} 
possibly reducing overall family welfare. This makes the relationship between hours of work and family welfare nonlinear. The dollar value of this change in family welfare is obtained by simply dividing the change in utility by the marginal utility of income $\left(U_{3}\right)$.

Utility function parameters are estimated separately for married and single families at different points on the income distribution, allowing preferences regarding trade-offs between leisure and consumption to vary by family income level, besides other correlating characteristics. ${ }^{6}$

\section{Estimation Issues}

Calculation of the average post-recession optimal labor supply $\left(h_{2011}^{*}\right.$ in Figure 1) depends on the estimation of labor supply elasticities of the husband and wife with respect to changes in their own and each other's wages, elasticities with respect to non-labor family income, as well as the changes in the probability of employment (extensive margin elasticities) (i.e., the probability of being at an interior solution on the budget constraint). There are many divergent empirical issues raised in the literature in relation to estimating labor supply responses to wage changes, i.e., estimates of labor supply elasticities. While the focus of this paper is on the simulation exercise itself, the simulation does require labor supply elasticities and it is therefore worthwhile to address some of the empirical issues. The goal here is to produce reasonable labor supply elasticities that are consistent with the literature. Toward that end, the methodology adopted takes the simplest approach possible while maintaining basic theoretical and empirical integrity.

The requirement of simplicity here primarily derives from the goal of quantifying the family-level utility changes. In order to obtain estimates of the pieces of the change in utility in

\footnotetext{
${ }^{6}$ As shown in Hotchkiss, et al (2012), wage elasticities and marginal utilities vary considerably across household income.
} 
equation (4) a specific functional form of utility must be specified. Following others (e.g., Hotchkiss et al. 2012, Heim, 2009, Hotchkiss et al., 1997, and Ransom, 1987), we estimate a quadratic form of the utility function: ${ }^{7}$

$$
U(Z)=\alpha(Z)-(1 / 2) Z^{\prime} \mathrm{B} Z,
$$

where $Z$ is a vector with elements $Z_{1}=T-h_{1}, Z_{2}=T-h_{2}$, and $Z_{3}=w_{1} h_{1}+w_{2} h_{2}+Y$; $\alpha$ is a vector of parameters and B is a symmetric matrix of parameters. This functional form has the advantage of belonging to the class of flexible functional forms in the sense that it can be thought of as a second order approximation to an arbitrary utility function (when B is positive definite). In addition, it is possible to produce analytical closed-form solutions for both the husband's and wife's labor supply functions. Obtaining the first order conditions of this unconstrained maximization problem results in a system of equations linear in $h:^{8}$

$$
\begin{gathered}
\frac{\partial U}{\partial h_{1}}=\Omega_{1} h_{1}+\Omega_{2} h_{2}+\Omega_{3}=0 \\
\frac{\partial U}{\partial h_{2}}=\Omega_{2} h_{1}+\Omega_{4} h_{2}+\Omega_{5}=0
\end{gathered}
$$

This system can be solved simultaneously, and the desired hours become $h_{1}^{*}=f\left(w_{1}, w_{2}, Y\right)$ and $h_{2}^{*}=g\left(w_{1}, w_{2}, Y\right)$, which represent the desired number of hours the members of a household would like to work, given the parameters that define their household utility function, given wages and non-labor income.

Observed hours $(\tilde{h})$, however, might differ from the optimum hours due to stochastic errors, such that:

$$
\tilde{h}_{1}= \begin{cases}h_{1}^{*}+e_{1} & \text { if } h_{1}^{*}+e_{1}>0 \\ 0 & \text { otherwise }\end{cases}
$$

\footnotetext{
${ }^{7}$ Details on the extension of this model to single households are presented in Appendix B.

${ }^{8}$ The components of and solution for desired hours are found in Appendix B.
} 


$$
\tilde{h}_{2}= \begin{cases}h_{2}^{*}+e_{2} & \text { if } h_{2}^{*}+e_{2}>0 \\ 0 & \text { otherwise }\end{cases}
$$

where we assume that $\left(e_{1}, e_{2}\right)$ follows a bivariate Normal distribution with mean 0 and covariance matrix $\sum$. This model can be thought of as a simultaneous Tobit model, where we have four kinds of families: those where both husband and wife work, those where only one of the spouses works ( 2 cases), and those where neither of them work. Allowing for hours adjustment along the extensive margin for the wife when assessing labor supply responses to wage changes have been found to make a significant difference when assessing total labor supply response (for example, see Heim, 2009 and Eissa et al., 2004), however, extensive margin hours adjustments appear to be unimportant for men (for example, see Heim, 2009, Blundell et al., 1988). Considering the simulation of suboptimal labor market outcomes that we plan to conduct allowing for non-working husbands may be important, so we opt to include them in the analysis.

The presence of non-working wives and husbands raises one empirical issue identified by Keane (2010) that must be addressed: market wages are not observed for family members who do not work. To obtain estimates of those wages, we take the standard approach in the literature of estimating a selectivity-corrected wage equation (Heckman, 1974) on the sample of working men and women, using regressors observable for both working and nonworking individuals. ${ }^{9}$ The resulting parameter estimates are then used to predict wages for nonworking men and women based on their observable characteristics.

The maximum likelihood function corresponding to the joint labor supply optimization problem can be written as follows:

\footnotetext{
${ }^{9}$ For purposes of identification, the Heckman selection equation uses non-labor income, number of children in the household, and spouse education (for married households) as exclusion restriction variables.
} 


$$
\begin{aligned}
& L=\prod_{i=1}^{N}\left[\left(\frac{1}{\sigma_{1} \sigma_{2}}\right) \psi\left(\frac{\tilde{h}_{1}-h_{1}^{*}}{\sigma_{1}}, \frac{\tilde{h}_{2}-h_{2}^{*}}{\sigma_{2}}, \rho\right)\right]^{(H=1, W=1)} \\
& *\left[\frac{1}{\sigma_{1}} \varphi\left(\frac{\tilde{h}_{1}-h_{1}^{*}}{\sigma_{1}}\right)\left\{1-\Phi\left(\frac{\sigma_{1} h_{2}^{*}-\rho \sigma_{2}\left(\tilde{h}_{1}-h_{1}^{*}\right)}{\sigma_{2} \sigma_{1} \sqrt{1-\rho^{2}}}\right)\right\}\right]^{(H=1, W=0)} \\
& *\left[\frac{1}{\sigma_{2}} \varphi\left(\frac{\tilde{h}_{2}-h_{2}^{*}}{\sigma_{2}}\right)\left\{1-\Phi\left(\frac{\sigma_{2} h_{1}^{*}-\rho \sigma_{1}\left(\tilde{h}_{2}-h_{2}^{*}\right)}{\sigma_{2} \sigma_{1} \sqrt{1-\rho^{2}}}\right)\right\}\right]^{(H=0, W=1)} \\
& * \Psi\left(\frac{-h_{1}^{*}}{\sigma_{1}}, \frac{-h_{2}^{*}}{\sigma_{2}}, \rho\right)^{(H=0, W=0)}
\end{aligned}
$$

Where $\varphi$ and $\Phi$ correspond to the probability density and cumulative distribution functions of a univariate normal, and $\psi$ and $\Psi$ represent the probability density and cumulative distribution functions of the bivariate normal. Also, $\mathrm{H}=1$ if the husband is working and $\mathrm{W}=1$ if the wife is working ( 0 otherwise), $\sigma_{i}(i=1,2)$ represents the standard deviations of $\left(e_{1}, e_{2}\right)$ and $\rho$ is the correlation between the stochastic errors.

The stochastic errors accounted for in equation (9) represent errors in optimization -observed hours do not exactly reflect desired hours. ${ }^{10}$ Keane (2010) points out that there may exist measurement error in observed wages and non-labor income. This classical measurement error may bias elasticity estimates toward zero. Heim (2009), using a methodology most similar to the one used here, presents results showing that accounting for measurement error produces elasticities practically identical to when it is not accounted for. A typical strategy to mitigate the introduction of measurement error on wages per hour has been to restrict the sample to hourly paid workers. Unfortunately, we cannot restrict the sample to workers paid weekly or hourly, since the American Community Survey (ACS) does not provide information on hourly or weekly wages. Instead, we construct the person's hourly wage using information about weeks worked

\footnotetext{
${ }^{10}$ These errors, however, are not expected to reflect suboptimal outcomes that might be observed because of labor market constraints (as we might expect exist post-recession).
} 
per year and usual hours worked per week. This means our wage estimate might suffer from what Keane refers to as "denominator bias," which will have the tendency of biasing labor supply elasticities downward.

Keane (2010) also identifies two potential sources of endogeneity. First, it is reasonable to expect that observed wages and non-labor income are correlated with a person's taste for work (reflected through hours of work). Both fixed effects and instrumental variables have been used to resolve this issue, but are simply not possible in this case since we do not have panel data and because of the highly non-linear nature of the labor supply functions. In addition to the inclusion of variables expected to affect the taste for work (e.g., children), we expect that the inclusion of spousal variables (through the estimation of joint labor supply) will help to remove additional sources of correlation from the error term (i.e., because of positive assortative mating, people with similar taste for work will be married to each other; see Lam, 1988, Hernstein and Murray, 1994). In addition, we abstract from the progressivity of the tax structure by using gross wages and estimating utility function parameters separately for families at different points in the income distribution. This amounts to "linearizing" the budget constraint (see Hall 1970), which is valid if preferences are strictly convex. ${ }^{11}$ This means that family members would make the same hours choice facing this linearized budget constraint that they would have made facing the nonlinear budget constraint. If this assumption is binding, Keane points out that labor supply elasticities will be biased in a negative direction.

An additional concern Keane (2010) identifies in the literature is making sure the hours/wage combinations observed in the data are coming off workers' labor supply curve, rather

\footnotetext{
${ }^{11}$ This assumption of strictly convex preferences is supported by a positive definite B matrix. As it will be seen, all the eigenvalues of the estimated $\mathrm{B}$ matrices are positive, indicating the matrix itself is positive definite.
} 
than off employers' labor demand curve. Identification of the labor supply relationship boils down to including regressors (determinants of hours) that reflect the demand for a person's skills (thus determine the observed wage) that are not reflective of that person's taste for work. Toward that end, we include an indicator for race that could affect observed wage through employer discrimination, but, ceteris paribus (e.g., education), should not affect taste for work.

Further, the issue of the presence of fixed costs of working is raised by Apps and Rees (2009). We only marginally control for fixed costs by including the presence of children in the determination of hours. However, Heim (2009) presents results showing that once demographics are controlled for, additional consideration of fixed costs only very slightly impacts estimates of the parameters of the utility function (Heim, Table 3).

\section{Use of a Synthetic Panel}

The goal of this paper is to analyze the impact of the recession on changes in welfare through changes in market wages and non-labor income. One possibility would be to use repeated (pre- and post-recession) observations on the same sample of families through the use of a long panel dataset in order to observe how the recession affected wages, non-labor income, hours worked, and unemployment for each individual member of the household. While the Panel Study of Income Dynamics (PSID) might seem an obvious candidate, as it provides a long panel of data, it doesn't contain enough observations to produce reliable estimates across income groups. In addition, the use of a panel data set would confound the welfare impact of changes in the labor market with other behavioral changes households went through during this period (i.e. changes in the household structure, parenthood, improving education, divorce rates, among others).

Alternatively, the analysis in this paper makes use of a synthetic panel based on detailed 
family characteristics, so that households in 2007 can be paired with similar households in 2011. The primary advantages of this approach are (1) we can make use of much larger cross-section data sets in order to improve estimation precision, and (2) we can isolate the impact of labor market changes from behavior or characteristic changes -- it's as close to a controlled experiment that we can get. Details of how this synthetic panel is constructed are contained in the next section.

III. Data

The American Community Survey (ACS) is a national random survey collected by the U.S. Census every year since 2000. The survey is sent to approximately 250,000 households every month. The ACS was designed to replace the decennial Census long form, and to be able to provide reliable demographic, housing, social, and economic data, for states and local areas, annually. From 2005, the ACS collects information for approximately $1 \%$ of the population, containing approximately 1.2 million household records.

\section{A. Sample Creation}

For the analysis in this paper, we use data from the 2007 American Community Survey (ACS) to estimate the pre-recession family utility function parameters used in the microsimulation, and data from 2011 to obtain a picture on labor market supply post-recession. ${ }^{12}$ In order to estimate the joint household labor supply, the sample is restricted as follows:

- Husband and wife present,

- Husband and wife age between 25 and 64 years old,

- Households with unmarried same- or opposite sex adults/partners are excluded, and

- Households where the age of the oldest child living in the household is $30 \mathrm{yrs}$ or younger.

In order to broaden the applicability of the analysis, households with single house holders are

\footnotetext{
${ }^{12}$ The reference period of relevant labor market variables (Income from wages and hours of work) corresponds to the past 12 months. As such, data collected in 2007 (2011) could reflect labor market experience anywhere between January 2006 (2010) and November 2007 (2011).
} 
also included in the sample (single household). The selection criteria for this sample are similar to above described, with the exception that the head of the household is single or not currently living with a spouse.

In addition, to reduce the noise from outliers in the sample, households with hourly wages at the top 0.5 percent and bottom 0.5 percent are excluded from the data, as well as households in the bottom three percent of the total income distribution. This leaves us with a total of $416,345(384,456)$ married households and $243,792(253,948)$ single households with single households for the 2007 (2011) sample.

\section{B. Simulation of the Great Recession}

For reasons detailed in the previous section, we construct a synthetic panel, creating cells of families with the same characteristics in 2007 and 2011. These cells are created based on detailed family characteristics that would not likely be affected by the recession itself. The household groups or "cells" are defined using all possible combinations on the following characteristics:

- 9 Census Divisions

- Dummy for living in the Metro Area

- If both husband and wife are present in the household (married or single household)

- Sex of the head of the household (single households only)

- Age combination of husband and wife (or single householder), using 5yr brackets

- Number of children between 0 to 5 yrs old $(0,1$, or 2 or more)

- Number of children 6yrs to 17 yrs old $(0,1,2,3$ or more)

- If there is any child $18 \mathrm{yr}$ or older living in the household

- Combinations of educational levels of Husband and Wife (Less than middle school, less than HS, High school, Some college, College, Grad school) (education level of single household)

- Race of the married couple: 0 White couple, 1 Non-white couple, 2 Mix couple (white or non-white for single household).

- Hispanic: If either the husband or wife is Hispanic.

Based on these characteristics, initially 183,000 household groups can be identified. For each identified cell with information available in 2007 and 2011, corresponding averages of 
selected variables (hours of work, employment rate, non-labor income) in 2011 are calculated and assigned to the 2007 households. In cases where families in 2007 cannot be matched with similar 2011 families, based on the most detailed characteristics, rather than dropping the information of the "unmatched" family groups, we re-define the criteria for family groups using less restrictive information (e.g., excluding the "Hispanic" characterization, using dummies for presence of children in the household, combining certain education groups, etc). The least restrictive criteria identify 2,002 unique family groups. In turn, average cell information from 2011 is assigned to the previously unpaired 2007 households groups based on the less restrictive grouping (e.g. an unmatched "Hispanic" family in 2007 would receive information from 2011 families regardless of their "Hispanic" designation).

Table 1 presents information on the rate of cell matching for households in 2007. From a total of 416,345 married households in 2007, 343,480 (82.5 percent) were paired using the most restrictive criteria. Only 107 households remain in groups that could not be matched even with the least restrictive cells. For single households, just over 99 percent of the sample was matched in the first round, with negligible number of observations being matched in later rounds.

[Table 1 here]

Figure 2 illustrates hours of work cell averages, for 2007 families alone, compared to the actual data. This gives us some idea about how accurate using cell averages for actual data will be. ${ }^{13}$ Figure 2 compares the distribution of actual hours worked in the previous year to the cell average hours worked, for couples and single households. The densities are estimated using

\footnotetext{
${ }^{13}$ The Cell averages could be thought as a nonlinear prediction of the number of hours worked, non-labor income, and employment rates, based on family characteristics. The total number of hours worked last year is calculated using the declared "usual number of hours worked per week," and multiplied by the number of weeks worked last year. In the absence of wages per hour, this variable is estimated as the result of total salaried wage income earned last year, divided by estimated total number of hours worked last year.
} 
household weights. We see that cell averages do a better job reflecting actual hours for husbands than for wives, but are equally good adjusting hours for single men and women. The cell averages clearly smooth through much of the clumping typically observed on integer values, but appear to replicate the actual distribution fairly well.

[Figure 2 here]

Figures 3, 4 and 5 provide an overview of how the labor supply changed between 2007 and 2011 (on average) across income deciles, based on pre-recession cell-average household income. While the data indicate the effect of the recession was fairly consistent across the middle income groups, there is some heterogeneity on the impact of the recession for high and low income households. The figures show that employment of both husbands and wives uniformly declined from 2007 to 2011 , except in the very lowest quintile. Regarding hours of work, Figure 4 shows that husbands across most of the income groups seem to have been affected in a similar way, working fewer hours on average in 2011 than in 2007, except for the poorest households. A similar pattern is observed in Figure 5, for singles. Wives, on the other hand, consistently increased their hours of work between 2007 and 2011 across all income groups, especially in the low-income households. ${ }^{14}$

[Figures 3, 4, and 5 here]

The synthetic panel is used to construct post-recession employment and hours outcomes for each person in the 2007 sample. Changes in wages and non-labor income are calculated from an exogenous data source--the outgoing rotation groups from the Current Population Survey (CPS), 2006-2007 and 2010-2011. Based on the same synthetic panel principle, cells from the CPS data are defined based on sex, education level, and five-year age groups, as those are the

\footnotetext{
${ }^{14}$ While single men and women are combined in Figure 5, they are separated for purposes of estimating labor supply elasticities and utility function parameters.
} 
principal factors that characterize wage profiles and wage growth. For each cell, average real wage growth is estimated, and assigned to each individual in the ACS 2007 sample.

Table 2 provides summary statistics comparing the probability of working and hours of work depicted in the figures above. In addition, the average wages and non-labor income (in real \$2007), as calculated from the CPS, are also reported. Wages fell more for husbands than wives, but, overall, real wages fell roughly by one percent between 2007 and 2011. Non-labor income fell more for married households (-14 percent) than for single households (-10 percent). ${ }^{15}$

[Table 2 here]

\section{$\underline{\text { IV. Results }}$}

\section{A. Utility Function Parameter Estimates and Labor Supply Elasticities}

Utility function parameters are estimated separately for two types of households, married households, where both husband and wife are present, and for single households, where the householder is single or the spouse is not present. Separate parameters are estimated for single male and single female households. In order to take into consideration the heterogeneity across income groups (Hotchkiss et al 2012), the models are estimated across income deciles within each type of households. ${ }^{16}$ Maximum likelihood estimation results are presented in Appendix C.

Theoretically, labor is supplied to the extent that the marginal utility of leisure is equal to the market wage, suggesting that, within a family, if husbands are paid more than wives,

\footnotetext{
${ }^{15}$ It's of interest to note that stagnating aggregate real wages have been noted in several places (e.g., Mishel and Shierholz 2013), disaggregated wages, for example by education level, have actually shown a real decline, suggesting that any increases (or non-declines) in the aggregate are the result of shifting demographics, such as increasing educational attainment.

${ }^{16}$ This strategy was preferred instead of using a single income classification for both single and married households, as there was a larger concentration of single households within the low income groups, with a similarly large concentration of married households in upper income groups.
} 
$U_{1}>U_{2}$. In addition, lower estimates of the marginal utilities of leisure would be consistent with greater values of labor supply, ceteris paribus. As the additional utility gained from an additional dollar of income increases at a decreasing rate, we would expect $U_{3}$ (marginal utility of consumption) to be smaller for higher income families. Figure 6 illustrates the estimated marginal utilities of leisure and income for families across income deciles, for married households and for single headed households. ${ }^{17}$ These figures show that the estimations of marginal utilities of leisure and consumption replicate the theoretical expectations for both married and single households.

[Figure 6 here]

Figure 7 presents average wage and income elasticities for husbands (Panel a), wives (Panel b), single men (Panel c), and single women (Panel d). Own wage elasticities for husbands and wives are averages across working and non-working spouses. Cross wage elasticities for husbands and wives correspond to families in which both members are working. Recall that linearizing the budget constraint (and denominator bias in the measurement of wages) can bias labor supply elasticities in a negative direction (Keane, 2010). While this could explain the estimation of negative own wage hours elasticities for husbands in the lower end of the income distribution, these are not inconsistent with estimates reported by Kaiser et al (1992) for Germany; and Ransom (1987), MaCurdy et al. (1990), and Pecanvel (2002) using U.S. data. ${ }^{18}$

[Figure 7 here]

Among all families, wives' own wages elasticities are much higher than husbands' elasticities, indicating that wives' labor supply is more responsive to changes in their own wages.

\footnotetext{
${ }^{17}$ For single households, the quintiles are defined based on the full sample, rather than the individual male/female headed household groups.

${ }^{18}$ Similar to Ransom (1987), while the uncompensated wage elasticity is negative albeit small, the corresponding compensated own wage elasticity for husbands is positive and around 0.2.
} 
These estimates for wives' own labor supply elasticities are mostly within the range reported in the literature using U.S. data. ${ }^{19}$ The estimated negative cross-wage elasticities across all income levels indicate that husbands and wives view their leisure time as substitutes; this is consistent with cross-elasticities estimated by in Hotchkiss et al. (2012), Heim (2009), Ransom (1987). Both husbands and wives present the expected low and negative income elasticity, although wives are slightly more responsive to changes in non-labor income than their husbands.

With respect to single headed households, on average, the householders present a positive own wage elasticity, decreasing monotonically with income, as would be expected. The estimated income elasticity is also negative, as expected. Also, as would be expected, labor supply elasticities of single men and women are more similar than elasticities of married men and women.

\section{B. Estimated Welfare Impact}

The accurate estimation of the welfare impact of the Great Recession depends on accurate estimates of optimal labor supply post-recession. In order to assess the accuracy of those estimates we use the estimated model parameters to predict optimal pre-recession employment and hours of work and compare those predictions to the observed outcomes. The details are contained in Appendix D, but the bottom line is that the model generally overstates employment probabilities and understates hours of work. The implication of these two results is that labor supply elasticities will be under-estimated and, therefore, the change in family welfare reported here will be biased toward zero.

Figure 8 presents the change (mostly loss) in welfare experienced by families moving

\footnotetext{
${ }^{19}$ For example, the range of estimates found in Cogan (1981), Hausman (1981), Triest (1990), Ransom (1987), Hotchkiss et al. (1997), and Blau and Kahn (2005) is 0.12 to 0.97. Also see Killingsworth (1983:107) and Hotchkiss et al. (2012).
} 
from their optimal hours and consumption combination pre-recession to their predicted optimal combination post-recession, and finally to the actual outcome post-recession. ${ }^{20}$ These results take into account both the change in hours and consumption experienced on the intensive margin (on the budget constraint), as well as taking into account the change in probability of being employed in the two time periods. The results for the lowest quintile indicate that after the recession, both single women and married families have marginally improved their welfare. ${ }^{21}$ Two factors explain this. On the one hand, the utility loss from lower consumption that resulted from lower wages and fewer hours of work was partially compensated by a small increase in non-labor income among these households (see Table 3 discussed below). On the other hand, the marginal utility of leisure is large enough among first decile families that the utility gain from more leisure (fewer hours of work) helped to compensated for the utility loss from lower consumption. Both married and single families experienced increasing dollar-equivalent welfare losses as they moved up the income distribution.

[Figure 8 here]

Note in Figure 8 that the greatest share of total welfare loss across deciles derived from the wage and non-labor income changes from pre- to post-recession (the dashed line). On average, families only suffered relatively minor additional loss in welfare from constraints in the labor market (the difference between the dashed and solid lines). This makes sense as everyone was subjected to (typically) declines in real wages and non-labor income. But a relatively smaller portion of the labor force faced hours constraints (either through unemployment or working fewer hours than desired), making the average impact across all families smaller.

\footnotetext{
${ }^{20}$ Appendix A details the calculations and formulas used to calculate the change in family welfare between 2007 and 2011.

${ }^{21}$ Recall that when we are talking about the "lowest decile" this is post exclusion of families in the bottom three percent of the income distribution.
} 
The loss in welfare from the pre- to post-recession optimal hours/consumption combinations can be traced to the losses of real values in wages and non-labor income experienced by the average family in each decile, which are displayed in Table 3 ; these declines were larger among higher income families. The small average gains in non-labor income among the lowest deciles might have resulted from transfer payments benefiting the poor.

[Table 3 here]

Table 4 presents the welfare losses by household type across deciles as a percent of the decile's pre-recession total family income. The figures produce a picture nearly identical (except in scaling) to that of Figure 8. The greatest percentage loss accrued to married households in the top deciles, with single men and women generally experiencing greater percentage losses than married families, which is largely a function of their lower earnings and non-labor income. In addition, single men in the top decile didn't suffer any additional welfare loss between their predicted and actual hours worked in 2011. Single women in the lowest decile experienced the largest welfare gain as a percent of their pre-recession income, which is likely the result of the greatest opportunity for transfer payment being available to poor single women.

[Table 4 here]

\section{$\underline{\text { V. Conclusions and Implications }}$}

The analysis in this paper illustrates that for any given family the dollar equivalent welfare loss across the Great Recession could have been significant, and that it varied greatly across family income deciles. In fact, some of the lowest income families are estimated to have experienced a modest welfare gain across the recession, resulting primarily from smaller declines 
in wages than experienced by families at the upper end of the income distribution, and from an average increase in non-labor income.

On average, across all deciles, married families suffered a welfare loss equivalent to roughly $\$ 3,000$; single male household families suffered a welfare loss equivalent to about $\$ 1,400$; and single female household families suffered a welfare loss equivalent to about $\$ 1,100$. In 2007, there were approximately 56 million married couple households, 5 million single male headed households, and 14 million single female headed households (Kreider and Elliott 2009). This means the total welfare loss accruing to families in the U.S. from the recession amounts to roughly $\$ 190$ billion. To put this into perspective, total personal income in the U.S. in 2007 is estimated to have been about $\$ 11,900$ billion (BEA 2007); the welfare loss amounts to 1.6 percent of this total income. Note, this is roughly in the same ballpark of the roughly two percent average welfare loss calculated as a percent of individual family pre-recession income seen in Table 4. Of course, this is a static welfare loss and does not take into account losses incurred by families during 2008 and 2009, or any losses experienced from labor market transitions (e.g., Jacobson et al. 1993 and Sullivan and vonWachter 2009 ). The estimate also doesn't directly account for policies undertaken to mitigate the impact of the recession, such as the American Recovery and Reinvestment Act of 2009. 


\section{$\underline{\text { References }}$}

Apps, Patricia and Ray Rees, Public Economics and the Household, Cambridge University Press, 2009.

Bahl, Roy; Richard Hawkins; Robert E. Moore; and David L. Sjoquist. "Using Microsimulation Models for Revenue Forecasting in Developing Countries." Public Budgeting and Financial Management 5(1) (1993): 159-86.

Bargain, Olivier and Nicolas Moreau, "Is the Collective Model of labor Supply Useful for Tax Policy Analysis? A Simulation Exercise," CESifo Working Paper No. 1052, October 2003.

BEA. "News Release: Personal Income and Outlays." U.S. Department of Commerce, Bureau of Economic Analysis (30 March 2007), http://www.bea.gov/newsreleases/national/pi/2007/pi0207.htm (accessed 28 July 2014).

Blau, Francine D. and Lawrence M. Kahn, "Changes in the Labor Supply of Married Women: 1980-2000," NBER Working Paper \#1 1230, March 2005.

Blundell, Richard, "Labour Supply and Taxation: A Survey," Fiscal Studies 13(3), 15-40, 1992.

Blundell, Richard; Alan Duncan; Julian McCrae; and Costas Meghir, "The Labour Market Impact of the Working Families' Tax Credit," Fiscal Studies 21(1), 75-104, 2000.

Blundell, Richard; Costas Meghir; Elizabeth Symons; and Ian Walker, "Labour Supply Specification and the Evaluation of Tax Reforms," Journal of Public Economics 36, 23$52,1988$.

Blundell, Richard; Pierre-Andre Chiappori; and Thierry Magnac, "Collective Labour Supply: Heterogeneity and Non-participation," Review of Economic Studies 74, 417-45, 2007.

Cogan, John F., "Fixed Costs and Labor Supply," Econometrica 49(4), 945-63, July 1981.

Eissa, Nada; Henrik Jacobsen Kleven; and Claus Thustrup Kreiner, "Evaluation of Four Tax Reforms in the United States: labor Supply and Welfare Effects for Single Mothers," Journal of Public Economics 92(3-4), 795-816, 2008.

Fiorio, Carlo V., "Analyzing Tax-Benefit Reforms Using Non-Parametric Methods," Fiscal Studies 29(4), 499-522, 2008.

Hausman, Jerry A., "The Effect of Taxes on Labor Supply," In H. Aaron and J. Pechman, eds, How Taxes Affect Economic Behavior, Brookings, Washington D.C., 1981. 
Heckman, J. J., "Shadow prices, market wages, and labor supply,” Econometrica 42, 679-93, 1974.

Heim, Bradley T., "Structural Estimation of Family Labor Supply with Taxes," Journal of Human Resources 44(2), 350-85, Spring 2009.

Hernstein, Richard J. and Charles Murray, The Bell Curve: Intelligence and Class Structure in American Life, Simon and Schuster, Free Press, New York; London; and Toronto, 1994.

Hotchkiss, Julie L.; Mary Mathewes Kassis; and Robert E. Moore, "Running Hard and Falling Behind: A Welfare Analysis of Two-Earner Families," Journal of Population Economics 10(3) (August 1997): 237-50.

Hotchkiss, Julie L.; Robert E. Moore; and Fernando Rios-Avila. "Assessing the Welfare Impact of Tax Reform: A Case Study of the 2001 U.S. Tax Cut." Review of Income and Wealth 58(2) (June 2012): 233-56.

Jacobson, Louis S.; Robert J. LaLoonde; and Daniel G. Sullivan. "Earnings Losses of Displaced Workers." American Economic Review 83(4) (September 1993): 685-709.

Kaiser, H,.Spahn, P. \& van Essen U., "Income taxation and the supply of labour in West Germany," Jahrbücher für Nationalökonomie und Statistik, 1992.

Keane, Michael P., "Labor Supply and Taxes: A Survey," Working Paper No. 160, University of Technology Sydney, July 2010.

Killingsworth, Mark R., Labor Supply, Cambridge University Press, Cambridge, 1983.

Kreider, Rose M. and Diana B. Elliott. America's Families and Living Arrangements: 2007. Washington, D.C.: U.S. Census Bureau, September 2009. http://www.census.gov/prod/2009pubs/p20-561.pdf

Kroft, Kory; Fabian Lange; Matthew J. Notowidigdo; and Lawrence F. Katz. "Long-term Unemployment and the Great Recession: The Role of Composition, Duration Dependence, and Non-participation." Mimeo, University of Toronto (September 2013). http://scholar.harvard.edu/files/lkatz/files/klnk_ltu_and_great_recession_sep16_2013.pdf

Lam, David, "Marriage Markets and Assortative Mating with Household Public Goods: Theoretical Results and Empirical Implications," Journal of Human Resources 23(4), 462-87, Autumn 1988.

Lansing, Kevin J. "Gauging the Impact of the Great Recession." FRBSF Economic Letter (11 July 2011). http://www.frbsf.org/economic-research/publications/economicletter/2011/july/impact-great-recession/ 
Lerman, Robert I. and Sisi Zhang. "Coping with the Great Recession: Disparate Impacts on Economic Well-being in Poor Neighborhoods." Washington, D.C.: The Urban Institute, 2012. http://www.urban.org/UploadedPDF/412728-Coping-with-the-GreatRecession.pdf

MaCurdy, T., Green, D. \& Paarsch, H., "Assessing Empirical Approaches for Analyzing Taxes and Labor Supply," The Journal of Human Resources, 25(3), 415-490, 1990.

McElroy, Marjorie B., "The Empirical Content of Nash-Bargained Household Behavior," The Journal of Human Resources 25(4), 559-83, Autumn 1990.

Mishel, Lawrence and Heidi Shierholz. "A Decade of Flat Wages." EPI Briefing Paper (21 August 2013). http://s1.epi.org/files/2013/BP365.pdf

Morgan, S. Philip; Erin Cumberworth; and Christophe Wimer. "Family, the Lifecourse, and the Great Recession." Stanford, CA: Stanford Center on Poverty and Inequality (October 2012). http://www.stanford.edu/group/recessiontrends-dev/cgi$\mathrm{bin} / \mathrm{web} /$ sites/all/themes/barron/pdf/Family_fact_sheet.pdf

Pencavel, J., "A Cohort Analysis of the Association between Work Hours and Wages among Men," The Journal of Human Resources, 37(2), 251-274, 2002.

Ransom, Michael R., "An Empirical Model of Discrete and Continuous Choice in Family Labor Supply," Review of Economics and Statistics, 465-72, August 1987.

Sullivan, Daniel and Till vonWachter. "Jobs Displacement and Mortality: An Analysis Using Administrative Data." Quarterly Journal of Economics 124(3): 1265-1306.

Sum, Andrew and Ishwar Khatiwada. "The Nation's Underemployed in the 'Great Recession' of 2007-09." Monthly Labor Review (November 2010): 3-15, http://www.bls.gov/opub/mlr/2010/11/art1 full.pdf

Triest, Robert K., "The Effect of Income Taxation on Labor Supply in the United States," Journal of Human Resources 25(3), 491-516, Summer 1990.

Warner, Judith. "What the Great Recession has Done to Family Life." NYTimes.com (6 August 2010). http://www.nytimes.com/2010/08/08/magazine/08FOB-wwln-t.html?_r=0 
Figure 1. Indifference curve reflecting different pre- and post-recession scenarios

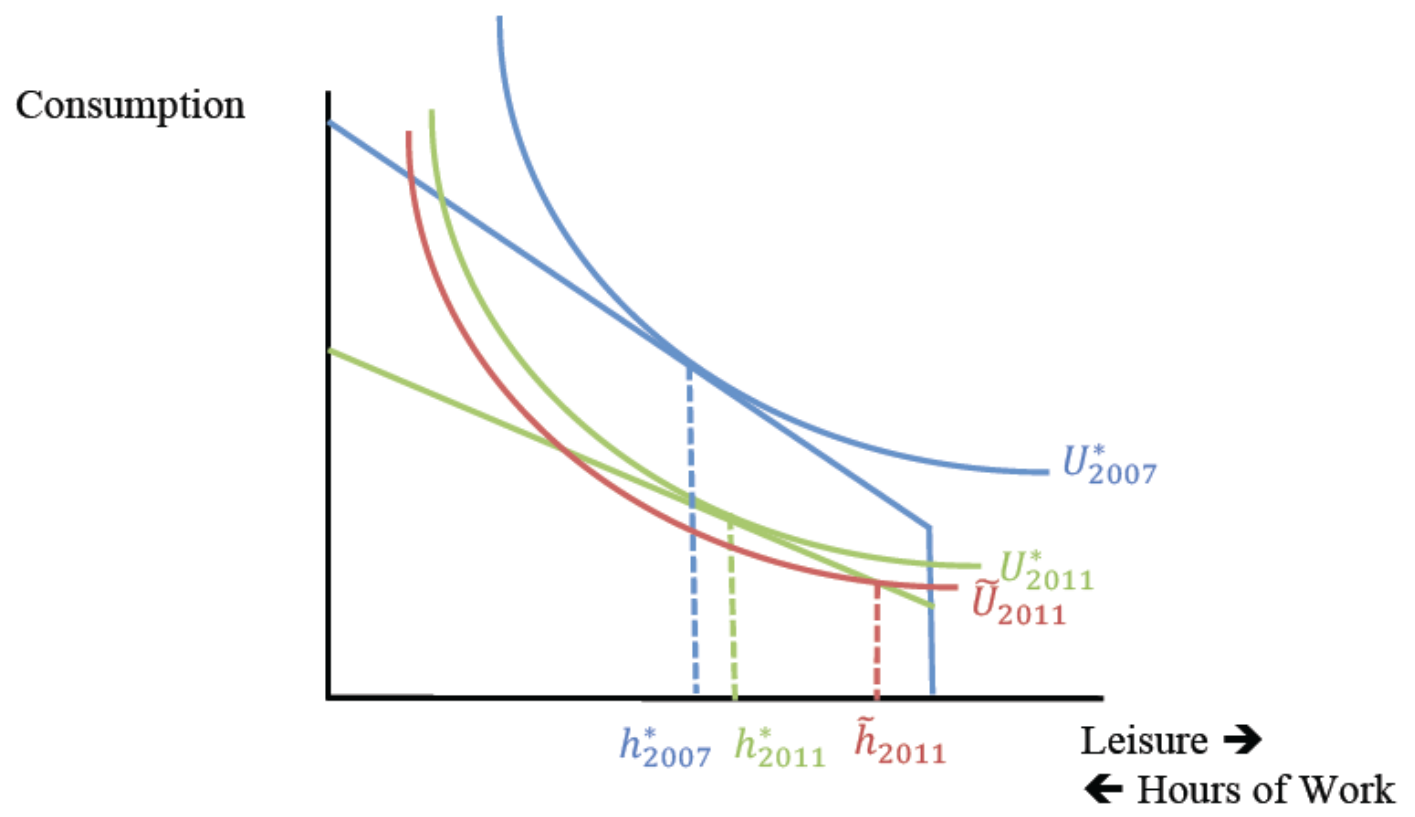

Figure 2. Distribution of hours worked last year in family cell averages and in the actual data, 2007 families.
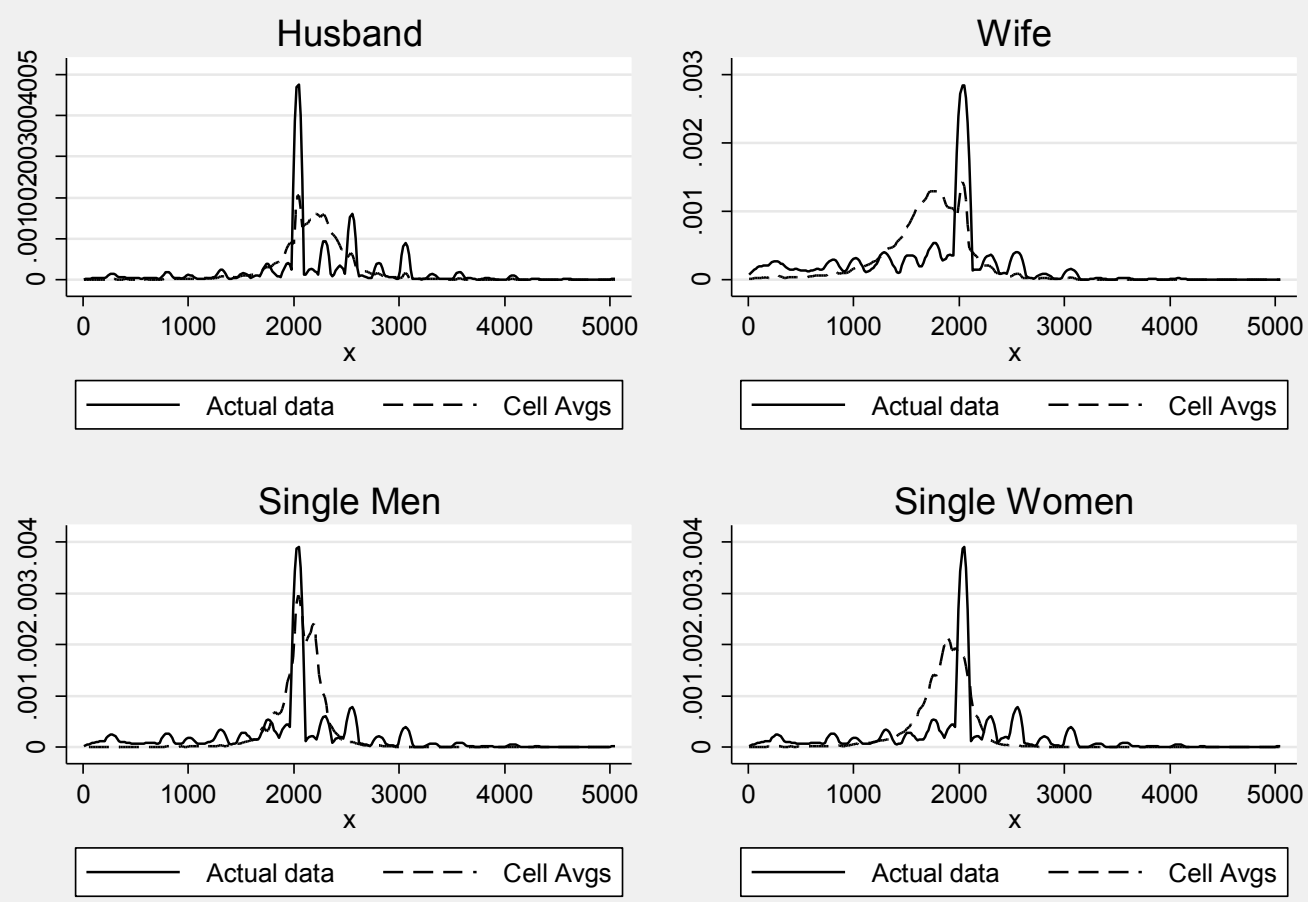
Figure 3. Share of people who worked during the last year, 2007 and 2011 married family cell averages by income decile.
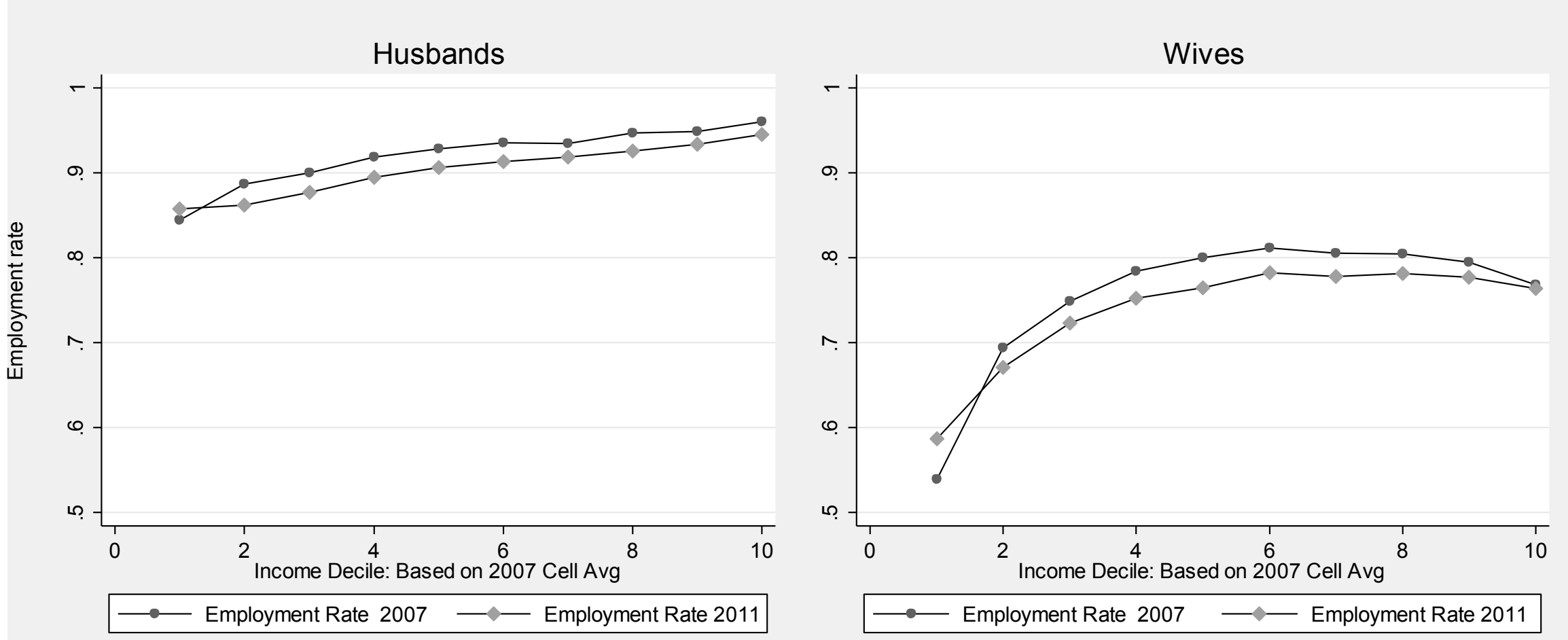
Figure 4. Total hours of work last year, workers only, 2007 and 2011 married family cell averages by income decile.
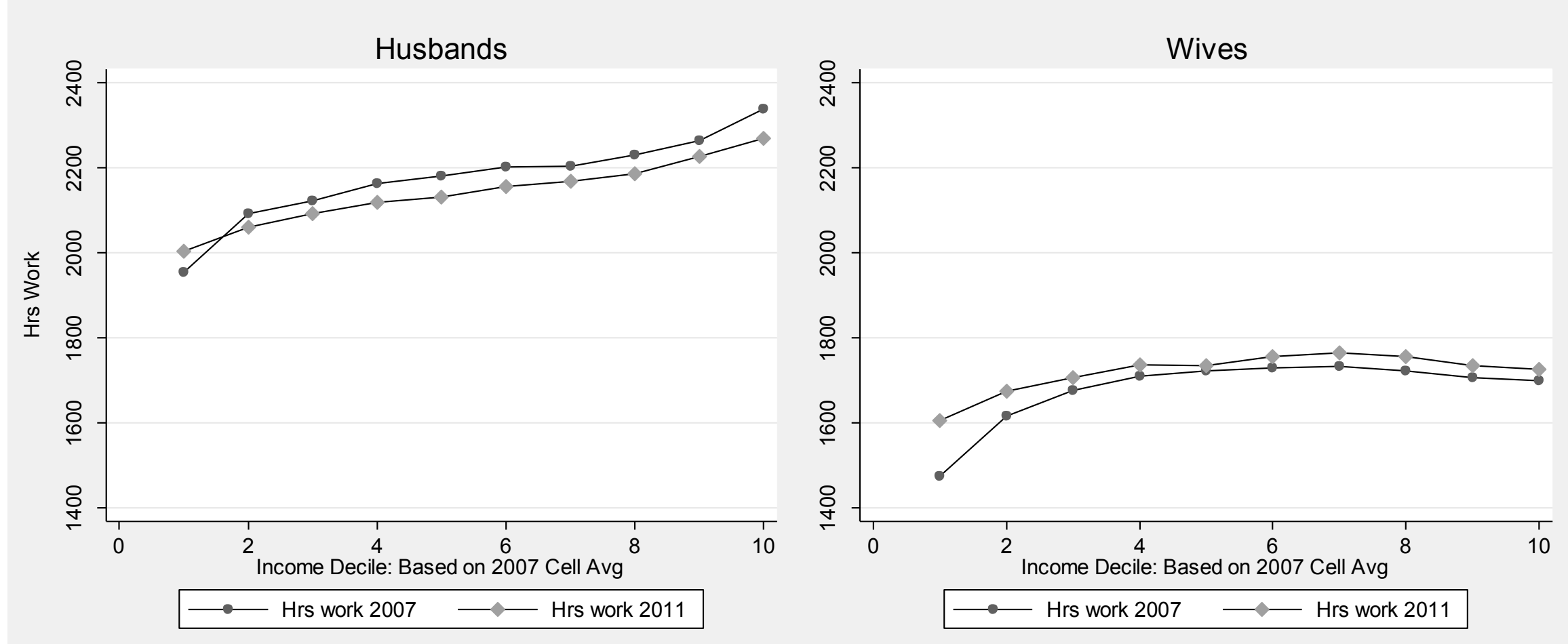

Note: Information is restricted to people with positive number of hours worked last year. 
Figure 5. Total hours of work last year, workers only, 2007 and 2011 single family cell averages by income decile.
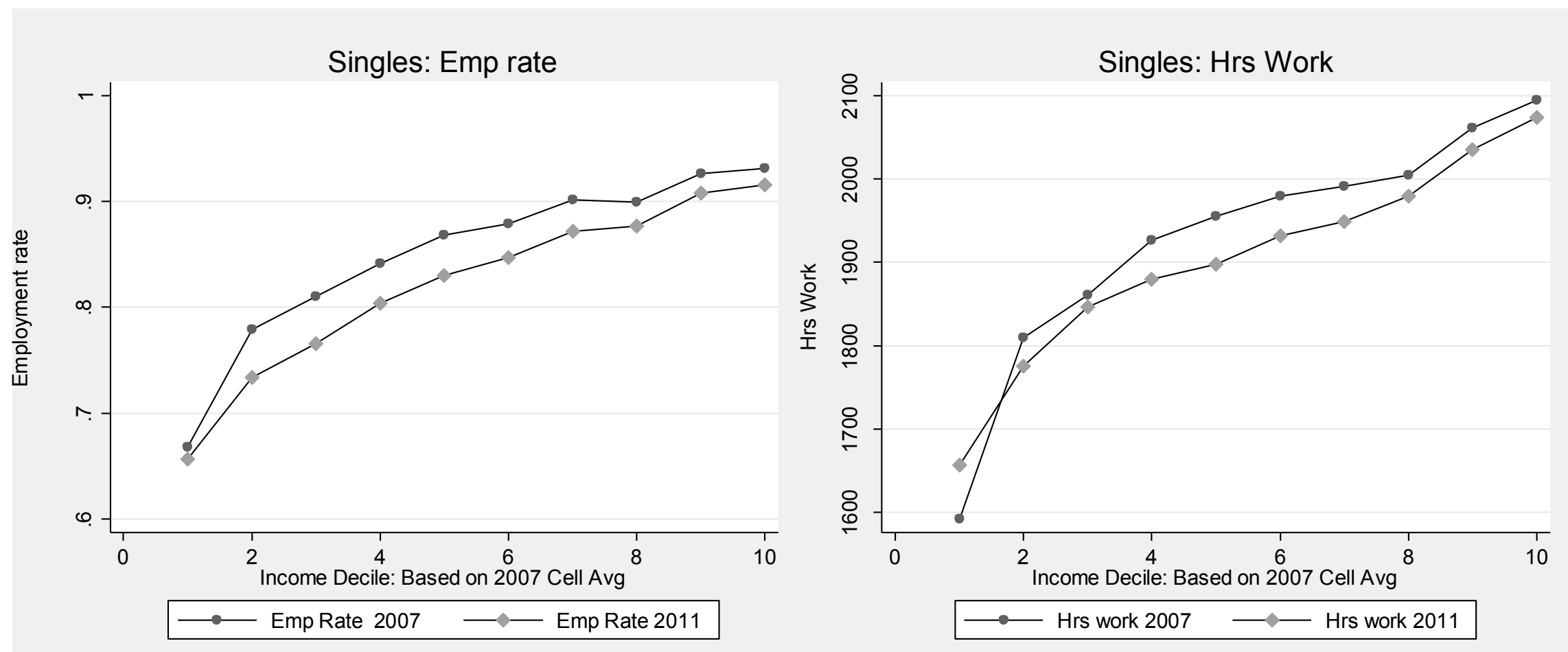

Note: Hours of work information is restricted to people with positive number of hours worked last year. 
Figure 6. Estimated marginal utilities of leisure and income, by income deciles of total family income.

Panel (a): Married Households

1500

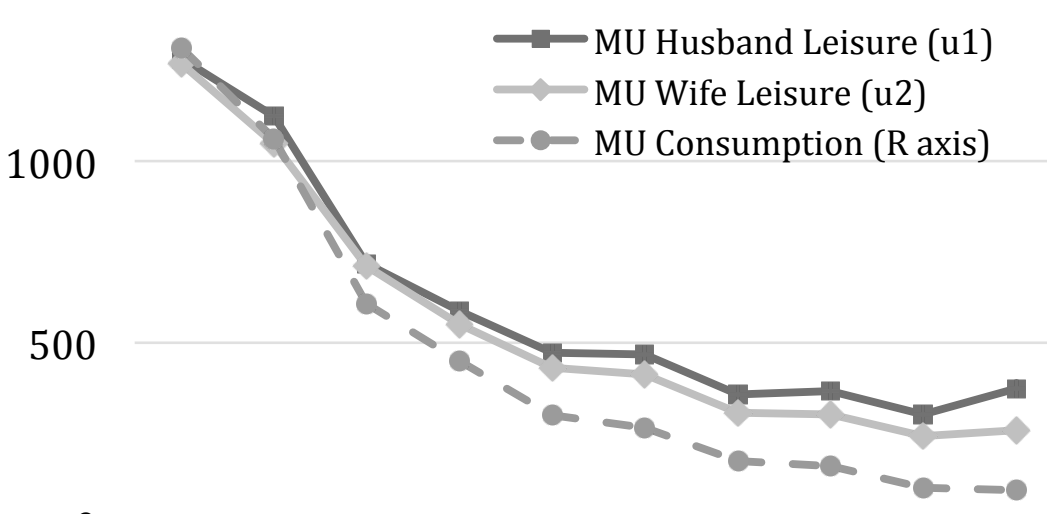

0

q1 q2 $\underset{\text { Income Deciles: Cell Avg Income }}{\mathrm{q} 3}$ q4 $\mathrm{q}$ (10
Panel (b): Single Households

100

10000

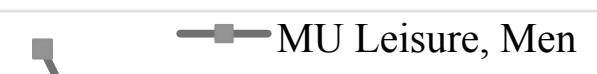

1500

80

60

40

20

0

0

$\rightarrow$ MU Leisure, Women

- - MU Consumptionm,Men ( $\mathrm{R}$ axis)

Q $-\mathrm{C}-\mathrm{MU}$ Consumption, Women (R axis)

5000

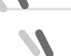

1

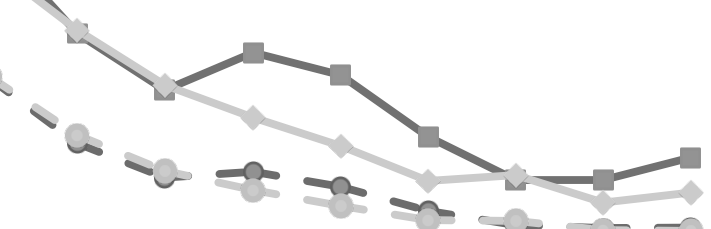

500

q1 $\quad$ q2 $\quad$ q3 $\quad$ q4 $\quad$ q5 $\quad$ q6 $\quad$ q7 $\quad$ q8 $\quad$ q9 $\quad$ q10 Income Deciles: Cell Avg Income 
Figure 7. Own and Cross Wage Elasticities and Income Elasticities, by income decile

Panel (a): Husbands

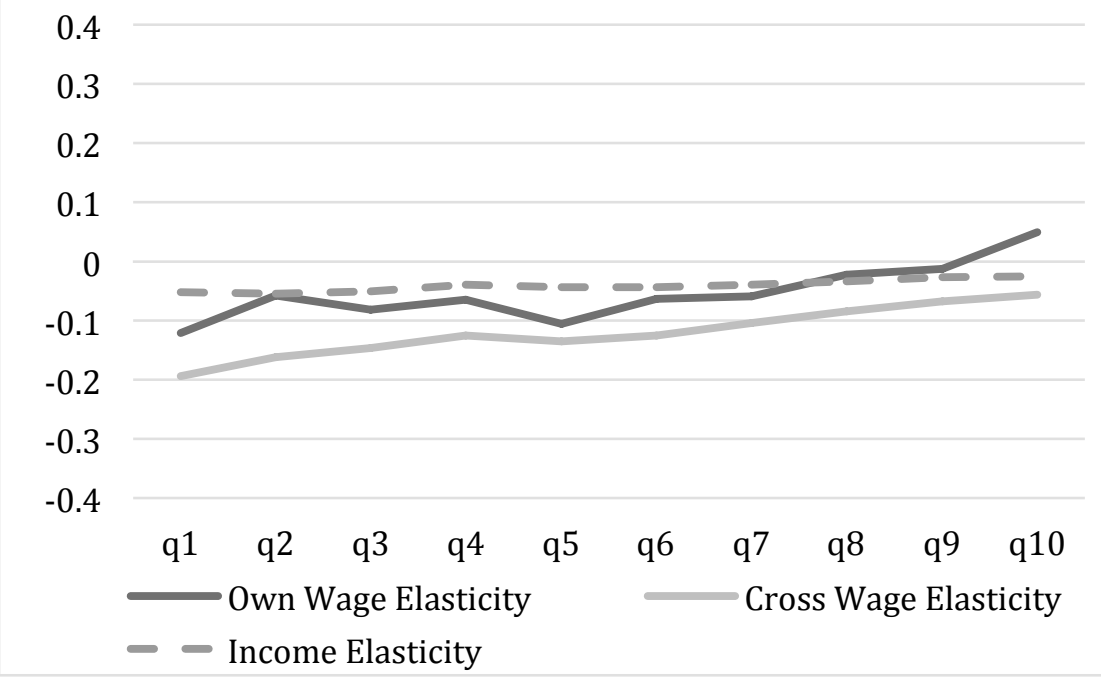

Panel (c): Single Men

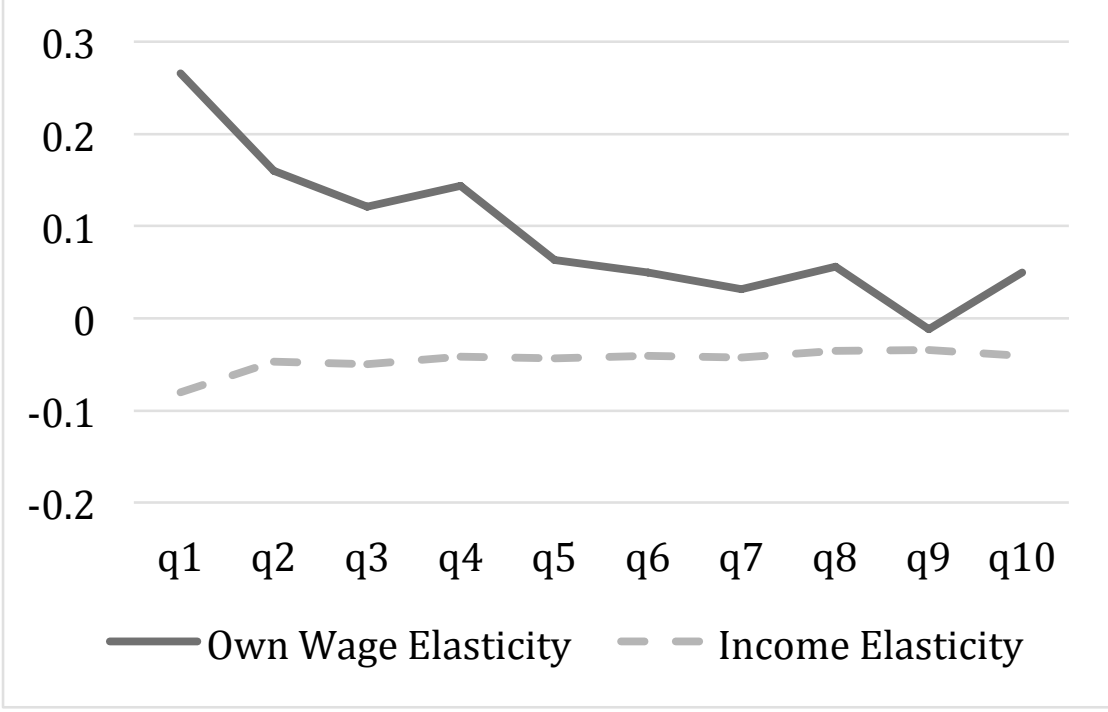

Panel (b): Wives

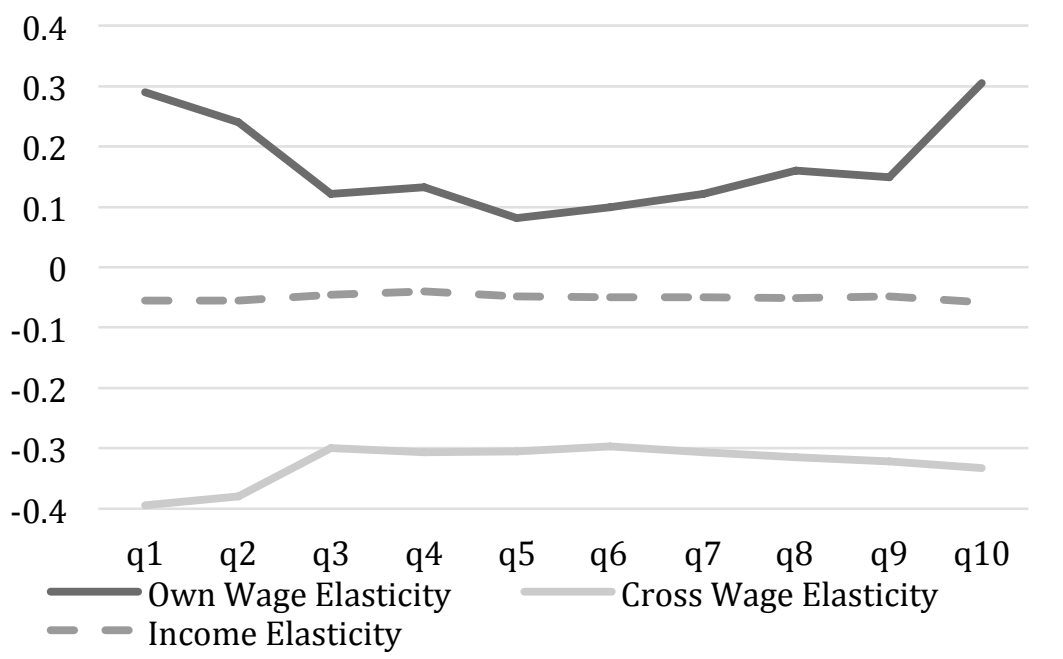

Panel (d): Single Women

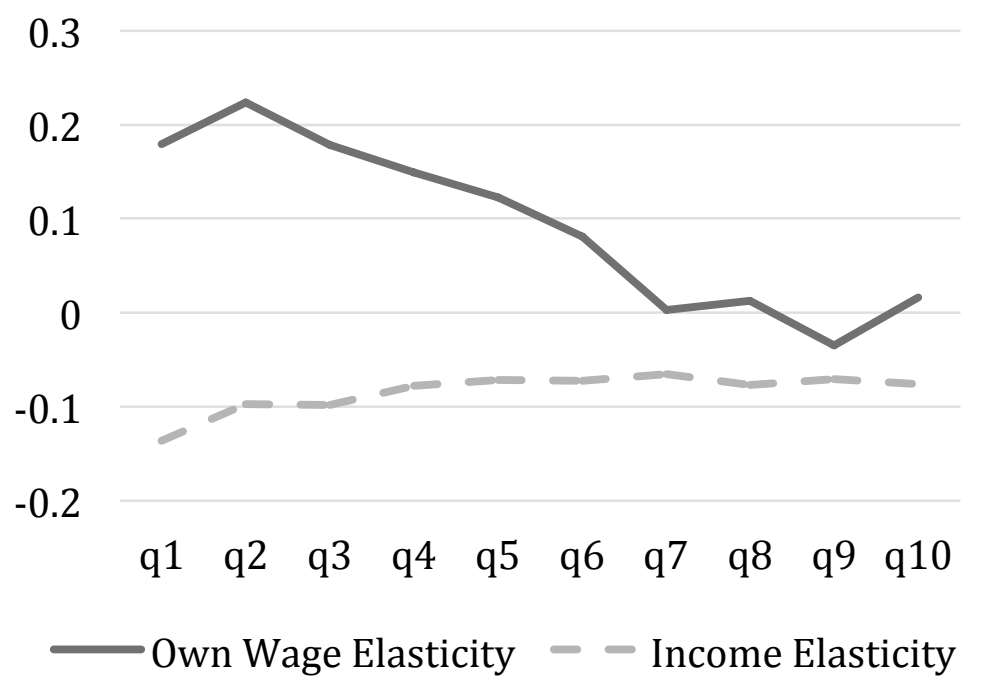


Figure 8. Simulated dollar-equivalent change in family welfare from pre-to post-recession by income deciles.

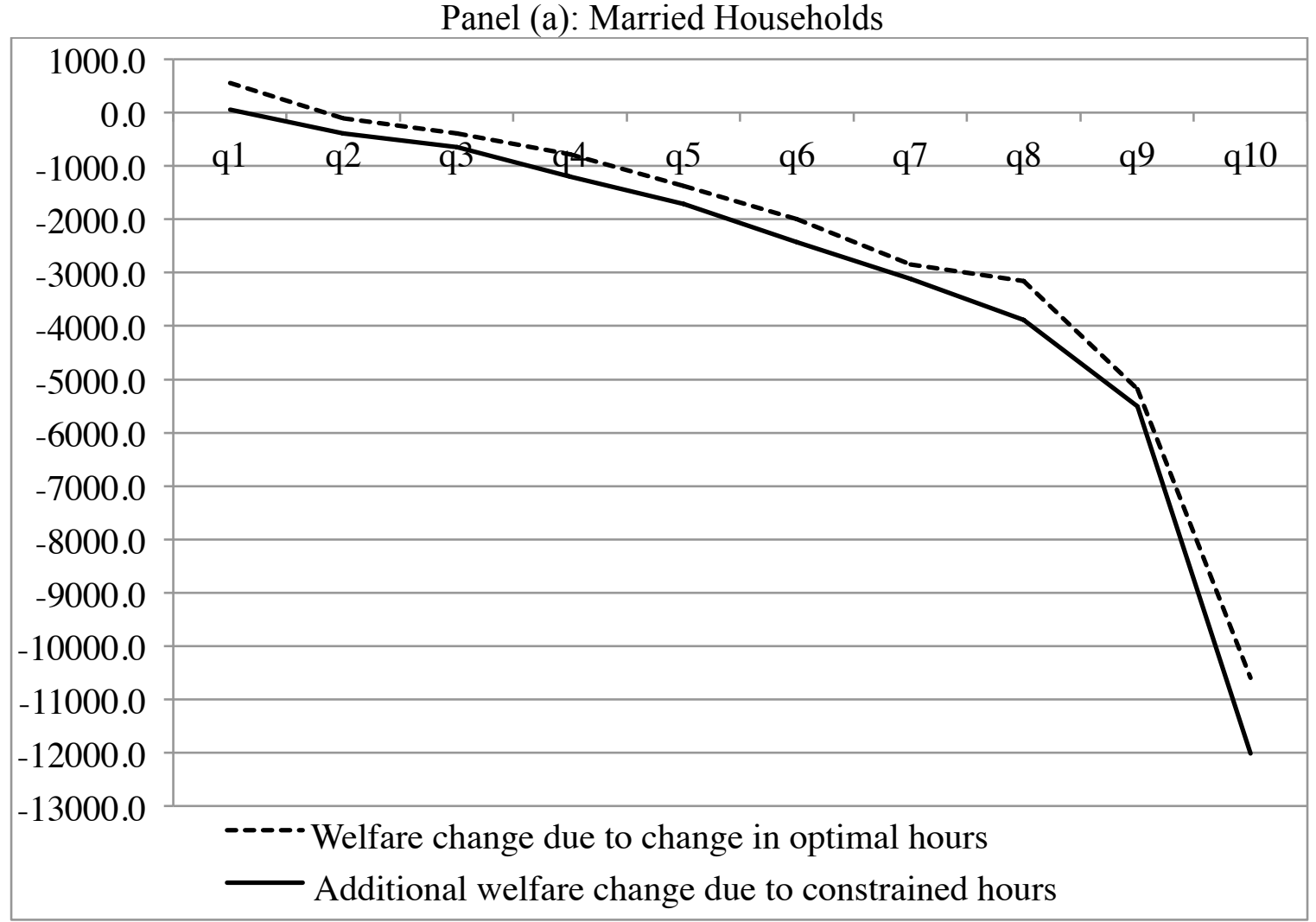

Panel (b): Single men

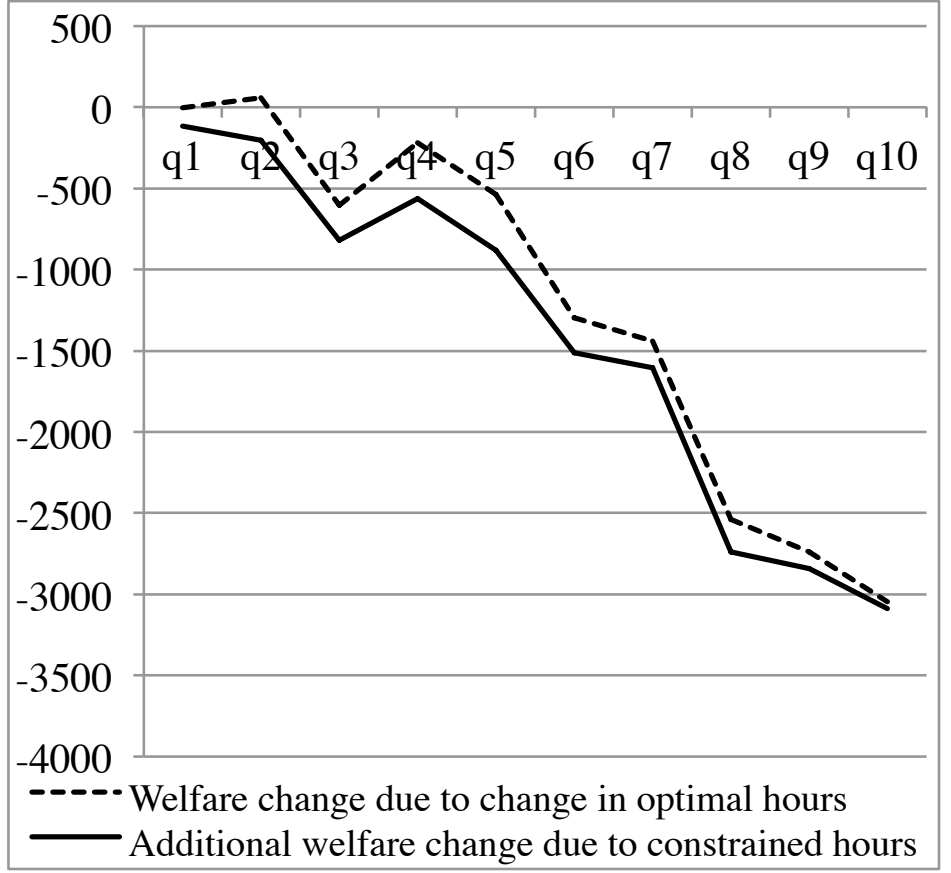

Panel (c): Single women

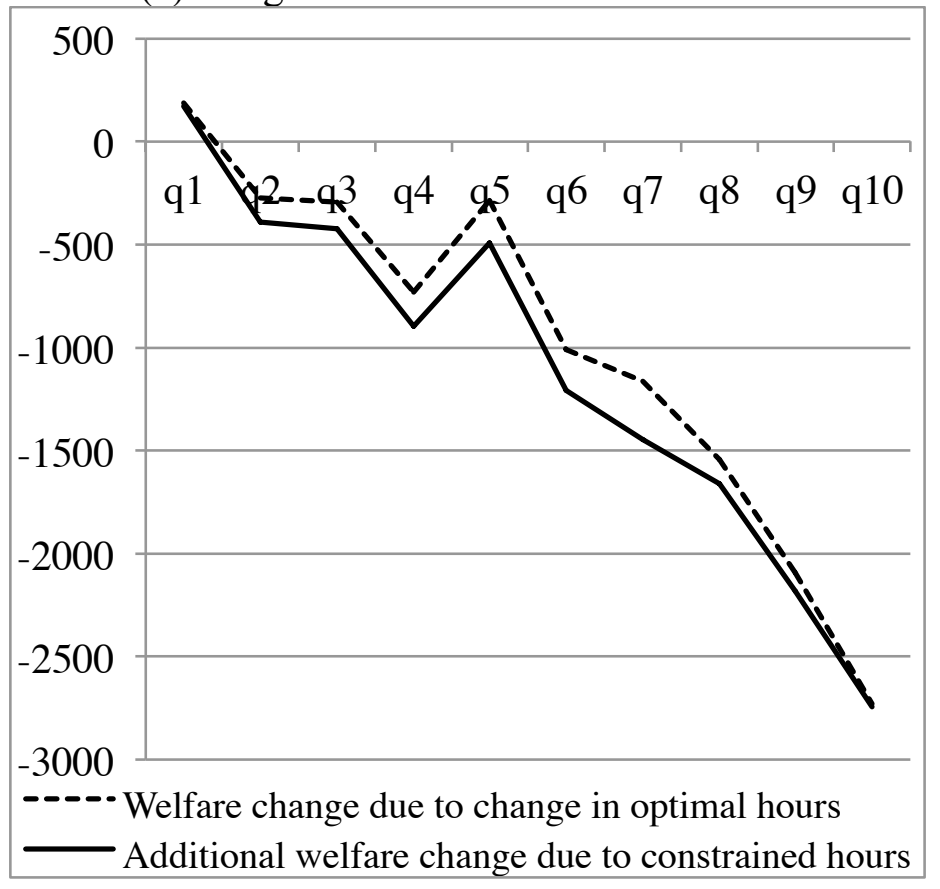


Table 1. Rates of matching 2007 family cells with 2011 families based on increasingly less restrictive criteria.

\begin{tabular}{|c|c|c|c|c|c|c|c|}
\hline \multirow[b]{2}{*}{ Round } & \multirow[b]{2}{*}{ Cumulative Match Criteria Adjustments } & \multicolumn{2}{|c|}{ Single Men } & \multicolumn{2}{|c|}{ Single Women } & \multicolumn{2}{|c|}{ Married Households } \\
\hline & & \#Households & Share & \#Households & Share & \#Households & Share \\
\hline 0 & All criteria included & 98,036 & 97.35 & 138,912 & 97.08 & 343,480 & 82.50 \\
\hline 1 & Exclude Hispanic & 685 & 0.68 & 1,619 & 1.13 & 13,032 & 3.13 \\
\hline 2 & $\begin{array}{l}\text { Use categories for number of children rather than } \\
\text { actual number }\end{array}$ & 1326 & 1.32 & 2,138 & 1.49 & 31,443 & 7.55 \\
\hline 3 & Reduce number of education categories & 294 & 0.29 & 185 & 0.13 & 3,677 & 0.88 \\
\hline 4 & $\begin{array}{l}\text { Additional reduction in number of education } \\
\text { categories }\end{array}$ & 140 & 0.14 & 81 & 0.06 & 620 & 0.15 \\
\hline 5 & $\begin{array}{l}\text { Reduction of age combination categories for } \\
\text { married couples }\end{array}$ & $\mathrm{n} / \mathrm{a}$ & & $\mathrm{n} / \mathrm{a}$ & & 14,358 & 3.45 \\
\hline 6 & Reduction in age categories overall & 103 & 0.10 & 90 & 0.06 & 7,309 & 1.76 \\
\hline 7 & Exclude indicator for children under five years & 74 & 0.07 & 45 & 0.03 & 1,435 & 0.34 \\
\hline 8 & Exclude metro/non-metro indicator & 34 & 0.03 & 18 & 0.01 & 616 & 0.15 \\
\hline 9 & Use Census Region rather than Census Division & 5 & 0.00 & 1 & 0.00 & 268 & 0.06 \\
\hline No match & & 6 & 0.01 & 0 & 0.00 & 107 & 0.03 \\
\hline \multicolumn{2}{|c|}{ Total number of Households } & 100,703 & & 143,089 & & 416,345 & \\
\hline
\end{tabular}


Table 2. Summary statistics, 2007 and matched 2011 family cell means.

\begin{tabular}{lrr}
\hline & 2007 Cell & 2011 Cell \\
Avg & Avg \\
\hline Couples & & \\
\hline Husband working = & $92.4 \%$ & $90.4 \%$ \\
Average total hours worked last year if working, husband & 2197.6 & 2155.6 \\
Wife working = & $75.5 \%$ & $73.8 \%$ \\
Average total hours worked last year if working, wife & 1711.8 & 1745.7 \\
Husband hourly wage & $\$ 29.6$ & $\$ 29.2$ \\
Wife hourly wage & $\$ 19.5$ & $\$ 19.3$ \\
Annual Non-labor Income & $\$ 10,837.0$ & $\$ 9,289.9$ \\
\hline Single Men & & \\
Working=1 & $87.2 \%$ & $84.3 \%$ \\
Average total hours worked last year if working & 2059.8 & 2013.5 \\
Hourly Wage & $\$ 22.6$ & $\$ 22.3$ \\
Annual Non-labor Income & $\$ 6,103.1$ & $\$ 5,438.0$ \\
Single Women & & \\
Working=1 & $84.7 \%$ & $81.4 \%$ \\
Average total hours worked last year if working & 1855.2 & 1834.9 \\
Hourly Wage & $\$ 18.8$ & $\$ 18.7$ \\
Annual Non-labor Income & $\$ 7,424.9$ & $\$ 6,716.2$ \\
\hline
\end{tabular}

Notes: Non-labor income is deflated to 2007 dollars. Wages are estimated using the CPS real wage growth. Means are estimated using 2007 household weights. 
Table 3. Changes in wages and family income from pre- to post-recession by deciles.

\begin{tabular}{|c|c|c|c|c|c|c|c|}
\hline \multirow[b]{2}{*}{$\begin{array}{l}\text { Income } \\
\text { Decile }\end{array}$} & \multicolumn{3}{|c|}{ Married Households } & \multicolumn{2}{|c|}{ Single Men } & \multicolumn{2}{|c|}{ Single Women } \\
\hline & $\begin{array}{c}\text { Average } \\
\text { change in } \\
\text { husband } \\
\text { wage } \\
\text { (dw1) }\end{array}$ & $\begin{array}{c}\text { Average } \\
\text { change in } \\
\text { wife wage } \\
\text { (dw2) }\end{array}$ & $\begin{array}{c}\text { Average } \\
\text { change in } \\
\text { family non- } \\
\text { labor income } \\
\text { (dY) }\end{array}$ & $\begin{array}{l}\text { Average } \\
\text { change } \\
\text { in wage } \\
(\mathrm{dw} 1)\end{array}$ & $\begin{array}{l}\text { Average } \\
\text { change in } \\
\text { family non- } \\
\text { labor } \\
\text { income } \\
\text { (dY) }\end{array}$ & $\begin{array}{l}\text { Average } \\
\text { change } \\
\text { in wage } \\
(\mathrm{dw} 1)\end{array}$ & $\begin{array}{l}\text { Average } \\
\text { change in } \\
\text { family non- } \\
\text { labor } \\
\text { income } \\
\text { (dY) }\end{array}$ \\
\hline $\mathrm{q} 1$ & $-\$ 0.22$ & $-\$ 0.18$ & $\$ 1,040.48$ & $-\$ 0.10$ & $\$ 169.7$ & $-\$ 0.18$ & $\$ 432.0$ \\
\hline $\mathrm{q} 2$ & $-\$ 0.23$ & $-\$ 0.16$ & $\$ 500.46$ & $-\$ 0.10$ & $\$ 259.2$ & $-\$ 0.17$ & $-\$ 25.9$ \\
\hline $\mathrm{q} 3$ & $-\$ 0.21$ & $-\$ 0.16$ & $\$ 224.59$ & $-\$ 0.16$ & $-\$ 342.7$ & $-\$ 0.13$ & $-\$ 109.0$ \\
\hline $\mathrm{q} 4$ & $-\$ 0.29$ & $-\$ 0.20$ & $\$ 66.99$ & $-\$ 0.20$ & $\$ 150.9$ & $-\$ 0.12$ & $-\$ 550.8$ \\
\hline q5 & $-\$ 0.35$ & $-\$ 0.18$ & $-\$ 388.06$ & $-\$ 0.24$ & $-\$ 96.0$ & $-\$ 0.05$ & $-\$ 211.2$ \\
\hline q6 & $-\$ 0.39$ & $-\$ 0.20$ & $-\$ 887.13$ & $-\$ 0.38$ & $-\$ 576.5$ & $-\$ 0.13$ & $-\$ 793.5$ \\
\hline $\mathrm{q} 7$ & $-\$ 0.45$ & $-\$ 0.16$ & $-\$ 1,622.11$ & $-\$ 0.37$ & $-\$ 746.6$ & $-\$ 0.24$ & $-\$ 739.5$ \\
\hline q8 & $-\$ 0.51$ & $-\$ 0.19$ & $-\$ 1,755.05$ & $-\$ 0.55$ & $-\$ 1491.8$ & $-\$ 0.17$ & $-\$ 1257.0$ \\
\hline q9 & $-\$ 0.54$ & $-\$ 0.19$ & $-\$ 3,607.33$ & $-\$ 0.56$ & $-\$ 1573.1$ & $-\$ 0.24$ & $-\$ 1652.6$ \\
\hline q10 & $-\$ 0.44$ & $-\$ 0.19$ & $-\$ 9,204.22$ & $-\$ 0.34$ & $-\$ 2290.4$ & $-\$ 0.13$ & $-\$ 2466.5$ \\
\hline
\end{tabular}

Note: Non-labor income and wages are deflated to 2007 dollars. 
Table 4. Dollar equivalent change in welfare as a percent of pre-recession family income.

\begin{tabular}{|c|c|c|c|c|c|c|}
\hline \multirow[b]{2}{*}{$\begin{array}{l}\text { Income } \\
\text { Decile }\end{array}$} & \multicolumn{2}{|c|}{ Married Households } & \multicolumn{2}{|c|}{ Single Men } & \multicolumn{2}{|c|}{ Single Women } \\
\hline & $\begin{array}{l}\text { Change in } \\
\text { welfare from } \\
2007 \text { optimal } \\
\text { hours to } 2011 \\
\text { optimal hours }\end{array}$ & $\begin{array}{c}\text { Change in } \\
\text { welfare from } \\
2007 \text { optimal } \\
\text { hours to } 2011 \\
\text { actual hours }\end{array}$ & $\begin{array}{c}\text { Change in } \\
\text { welfare from } \\
2007 \text { optimal } \\
\text { hours to } 2011 \\
\text { optimal hours }\end{array}$ & $\begin{array}{c}\text { Change in } \\
\text { welfare from } \\
2007 \text { optimal } \\
\text { hours to } 2011 \\
\text { actual hours }\end{array}$ & $\begin{array}{l}\text { Change in } \\
\text { welfare from } \\
2007 \text { optimal } \\
\text { hours to } 2011 \\
\text { optimal hours }\end{array}$ & $\begin{array}{c}\text { Change in } \\
\text { welfare from } \\
2007 \text { optimal } \\
\text { hours to } 2011 \\
\text { actual hours }\end{array}$ \\
\hline $\mathrm{q} 1$ & $1.4 \%$ & $0.2 \%$ & $0.0 \%$ & $-0.6 \%$ & $1.2 \%$ & $1.1 \%$ \\
\hline $\mathrm{q} 2$ & $-0.2 \%$ & $-0.7 \%$ & $0.2 \%$ & $-0.8 \%$ & $-1.3 \%$ & $-1.9 \%$ \\
\hline q3 & $-0.6 \%$ & $-1.0 \%$ & $-2.0 \%$ & $-2.7 \%$ & $-1.2 \%$ & $-1.7 \%$ \\
\hline $\mathrm{q} 4$ & $-1.1 \%$ & $-1.6 \%$ & $-0.6 \%$ & $-1.6 \%$ & $-2.5 \%$ & $-3.0 \%$ \\
\hline q5 & $-1.6 \%$ & $-2.0 \%$ & $-1.4 \%$ & $-2.2 \%$ & $-0.9 \%$ & $-1.5 \%$ \\
\hline q6 & $-2.1 \%$ & $-2.6 \%$ & $-2.9 \%$ & $-3.3 \%$ & $-2.7 \%$ & $-3.2 \%$ \\
\hline q7 & $-2.7 \%$ & $-2.9 \%$ & $-2.8 \%$ & $-3.1 \%$ & $-2.6 \%$ & $-3.3 \%$ \\
\hline $\mathrm{q} 8$ & $-2.6 \%$ & $-3.2 \%$ & $-4.2 \%$ & $-4.5 \%$ & $-3.0 \%$ & $-3.3 \%$ \\
\hline q9 & $-3.5 \%$ & $-3.8 \%$ & $-3.7 \%$ & $-3.8 \%$ & $-3.4 \%$ & $-3.6 \%$ \\
\hline q10 & $-5.3 \%$ & $-6.0 \%$ & $-3.1 \%$ & $-3.1 \%$ & $-3.5 \%$ & $-3.6 \%$ \\
\hline
\end{tabular}




\section{Appendix A: Formulas for simulating change in family welfare under different scenarios.}

In addition to changes interior to the budget constraint, we also want to take into account the changes to the probability of employment, which was significantly lower post-recession (higher unemployment). In order to do this, we make use of the implicit employment probability functions estimated in the model, which are used to estimate the extensive margin elasticities (how the probability of employment varies with wages and non-labor income) and the actual employment probabilities $\left(p_{1}\right.$ and $\left.p_{2}\right)$ in the pre-recession period. The employment probability functions are essentially the Tobit equivalent of the probability that hours of work are greater than zero. Predicted changes in the employment probabilities can be estimated as:

$d p_{1}=\frac{\partial p_{1}}{\partial w_{1}} d w_{1}+\frac{\partial p_{1}}{\partial w_{2}} d w_{2}+\frac{\partial p_{1}}{\partial Y} d Y$

$d p_{2}=\frac{\partial p_{2}}{\partial w_{1}} d w_{1}+\frac{\partial p_{2}}{\partial w_{2}} d w_{2}+\frac{\partial p_{2}}{\partial Y} d Y$

where, $d w_{1}=w_{1}^{2011}-w_{1}^{2007}, d w_{2}=w_{2}^{2011}-w_{2}^{2007}$, and $d Y=Y^{2011}-Y^{2007}$.

The predicted optimal change in hours in 2011, given 2007 utility function parameters, changes in wages and change in non-labor income are calculated as follows:

$d h_{1}^{*}=\left(\frac{p_{1,2007}+p_{1,2011}^{*}}{2}\right)\left(\frac{\partial h_{1}}{\partial w_{1}} d w_{1}+\frac{\partial h_{1}}{\partial w_{2}} d w_{2}+\frac{\partial h_{1}}{\partial Y} d Y\right)+d p_{1}\left(\frac{h_{1,2007}^{*}+h_{1,2011}^{*}}{2}\right)$

$d h_{2}^{*}=\left(\frac{p_{2,2007}+p_{2,2011}^{*}}{2}\right)\left(\frac{\partial h_{2}}{\partial w_{1}} d w_{1}+\frac{\partial h_{2}}{\partial w_{2}} d w_{2}+\frac{\partial h_{2}}{\partial Y} d Y\right)+d p_{2}\left(\frac{h_{2,2007}^{*}+h_{2,2011}^{*}}{2}\right)$

All of these changes (e.g., in probabilities of employment and hours) will be calculated for the

average decile cell. Note that $p_{j, 2011}^{*}=p_{j, 2007}+d p_{j}$ and $h_{j, 2011}^{*}=h_{j, 2007}^{*}+\left(\frac{\partial h_{j}}{\partial w_{1}} d w_{1}+\right.$

$\left.\frac{\partial h_{j}}{\partial w_{2}} d w_{2}+\frac{\partial h_{j}}{\partial Y} d Y\right)$ for $j=1,2$

Similarly, the change on consumption will be calculated as:

$d C^{*}=C_{2011}^{*}-C_{2007}$, and 


$$
\begin{aligned}
& C_{2007}=w_{1,2007} h_{1,2007}+w_{2,2007} h_{2,2007}+Y_{2007} \\
& C_{2011}=w_{1,2011}\left(h_{1,2007}+d h_{1}^{*}\right)+w_{2,2011}\left(h_{2,2007}+d h_{2}^{*}\right)+Y_{2011}
\end{aligned}
$$

Comparisons between optimal utility-maximizing outcomes in 2007 and 2011 are then calculated as follows::

$U_{2011}^{*}-U_{2007}^{*}=-\bar{U}_{1} d h_{1}^{*}-\bar{U}_{2} d h_{2}^{*}+\bar{U}_{3} d C^{*}$

where,

$\bar{U}_{1}=-a_{1}^{*}+b_{11} \bar{h}_{1}^{*}+b_{12} \bar{h}_{2}^{*}-b_{13} \bar{C}^{*}$,

$\bar{U}_{2}=-a_{2}^{*}+b_{12} \bar{h}_{1}^{*}+b_{22} \bar{h}_{2}^{*}-b_{23} \bar{C}^{*}$, and

$\bar{U}_{3}=a_{3}^{*}+b_{13} \bar{h}_{1}^{*}+b_{23} \bar{h}_{2}^{*}-b_{33} \bar{C}^{*}$

and $\bar{h}_{2}^{*}=\left[\frac{1}{2}\left(h_{2,2007}^{*}+h_{2,2011}^{*}\right)\right], \bar{h}_{1}^{*}=\left[\frac{1}{2}\left(h_{1,2007}^{*}+h_{1,2011}^{*}\right)\right]$, and $\bar{C}^{*}=\left[\frac{1}{2}\left(C_{2007}^{*}+C_{2011}^{*}\right)\right]$.

Note that the marginal utilities are calculated at the midpoint of hours and consumption, rather than at one point or the other.

Using the same formula, we can compare the predicted optimal utility outcome $\left(U_{2011}^{*}\right)$ with the suboptimal at observed (rather than predicted optimal) hours (note that $d Y$ here is the same at the $d Y$ above, so there is no contribution of the change in on-labor income to the comparison of optimal to suboptimal welfare outcomes):

$\widetilde{U}_{2011}-U_{2011}^{*}=-\widetilde{U}_{1} d \widetilde{h}_{1}-\widetilde{U}_{2} d \widetilde{h}_{2}+\widetilde{U}_{3} d \tilde{C}$

where,

$$
\begin{aligned}
& d \tilde{C}=w_{1,2011} d \tilde{h}_{1}+w_{2,2011} d \tilde{h}_{2} ; \\
& d \tilde{h}_{1}=\tilde{h}_{1,2011}-h_{1,2011}^{*}, \text { and } d \tilde{h}_{2}=\tilde{h}_{2,2011}-h_{2,2011}^{*} ; \\
& \widetilde{U}_{1}=-a_{1}^{*}+b_{11} \bar{h}_{1}+b_{12} \bar{h}_{2}-b_{13} \bar{C} ; \\
& \widetilde{U}_{2}=-a_{2}^{*}+b_{12} \bar{h}_{1}+b_{22} \bar{h}_{2}-b_{23} \bar{C} ;
\end{aligned}
$$


$\widetilde{U}_{3}=a_{3}^{*}+b_{13} \bar{h}_{1}+b_{23} \bar{h}_{2}-b_{33} \bar{C} ;$ and

$\bar{h}_{2}=\left[\frac{1}{2}\left(\tilde{h}_{2,2011}+h_{2,2011}^{*}\right)\right], \bar{h}_{1}=\left[\frac{1}{2}\left(\widetilde{h}_{1,2011}+h_{1,2011}^{*}\right)\right]$, and $\bar{C}=\left[\frac{1}{2}\left(\tilde{C}_{2011}+C_{2011}^{*}\right)\right]$.

Note that the marginal utilities are calculated at the average between the optimal and suboptimal hours and consumption, rather than at one point or the other. A simpler alternative would be to just use the 2011 suboptimal hours and consumption values. 


\section{Appendix B: First order conditions of utility maximization problem, labor supply equations, and likelihood function estimated.}

The quadratic functional form as presented in equation (5) in the text can also be written in the following form:

$U(Z)=a_{1}\left(L_{1}\right)+a_{2}\left(L_{2}\right)+a_{3}(C)-\frac{1}{2} b_{11}\left(L_{1}\right)^{2}-\frac{1}{2} b_{22}\left(L_{2}\right)^{2}-\frac{1}{2} b_{33}(C)^{2}-b_{12} L_{1} L_{2}-b_{13} L_{1} C-b_{23} L_{2} C$

Where $L_{1}=T-h_{1} ; L_{2}=T-h_{2} ;$ and, $C=w_{1} h_{1}+w_{2} h_{2}+Y$

This becomes an unconstrained utility maximization problem which depends on the working hours $h_{1}$ and $h_{2}$, assuming that $Y$ (non-labor income) is exogenous. The corresponding first order conditions become:

$\frac{\partial u}{\partial h_{1}}=a_{1}^{*}+a_{3}^{*} w_{1}-b_{11} h_{1}-b_{33} w_{1}\left(w_{1} h_{1}+w_{2} h_{2}+Y\right)-b_{12} h_{2}+b_{13}\left(2 w_{1} h_{1}+w_{2} h_{2}+Y\right)+b_{23} w_{1} h_{2}=0$

$\frac{\partial u}{\partial h_{2}}=a_{2}^{*}+a_{3}^{*} w_{2}-b_{22} h_{2}-b_{33} w_{2}\left(w_{1} h_{1}+w_{2} h_{2}+Y\right)-b_{12} h_{1}+b_{23}\left(w_{1} h_{1}+2 w_{2} h_{2}+Y\right)+b_{13} w_{2} h_{1}=0$

There is no need to specify a time endowment $(\mathrm{T})$ in order to estimate the labor supply functions because $a_{1}^{*}, a_{2}^{*}$, and $a_{3}^{*}$ are re-parameterized functions of T and $Y$. This re-parameterization is necessary for identification of the labor supply equations. It is through these starred parameters that differences in tastes across families are allowed to enter. Specifically, $a_{1}^{*}=X_{1} \Gamma_{1}$ and $a_{2}^{*}=X_{2} \Gamma_{2}$

where $X_{1}$ and $X_{2}$ are vectors of individual and family characteristics and $\Gamma_{1}$ and $\Gamma_{2}$ are parameters to be estimated.

Using equations (B2) and (B3), we can solve the system obtaining the values of $h_{1}$ and $h_{2}$ that maximize the utility function, in the following way:

$\Omega_{1} h_{1}^{*}+\Omega_{2} h_{2}^{*}+\Omega_{3}=0$

$\Omega_{2} h_{1}^{*}+\Omega_{4} h_{2}^{*}+\Omega_{5}=0$

Where: 


$$
\begin{aligned}
& \Omega_{1}=2 b_{13} w_{1}-b_{11}-b_{33} w_{1}^{2} ; \\
& \Omega_{2}=b_{23} w_{1}+b_{33} w_{1} w_{2}-b_{12}+b_{13} w_{2} ; \\
& \Omega_{3}=a^{*}{ }_{1}+a^{*}{ }_{3} w_{1}+\left(b_{33} w_{1}+b_{13}\right) Y ; \\
& \Omega_{4}=2 b_{23} w_{2}-b_{22}-b_{33} w_{2}^{2} ; \text { and } \\
& \Omega_{5}=a^{*}{ }_{2}+a^{*}{ }_{3} w_{2}+\left(b_{33} w_{2}+b_{23}\right) Y .
\end{aligned}
$$

From equations (B4) and (B5), the solutions for $h_{1}^{*}$ and $h_{2}^{*}$ become:

$$
\begin{aligned}
& h_{1}^{*}=\frac{\Omega_{3} \Omega_{4}-\Omega_{2} \Omega_{5}}{\Omega_{2}^{2}-\Omega_{1} \Omega_{4}} \\
& h_{2}^{*}=\frac{\Omega_{1} \Omega_{5}-\Omega_{2} \Omega_{3}}{\Omega_{2}^{2}-\Omega_{1} \Omega_{4}}
\end{aligned}
$$

Observed hours $(\tilde{h})$, however, can differ from optimum hours due to stochastic errors, such that:

$$
\begin{aligned}
& \tilde{h}_{1}= \begin{cases}h_{1}^{*}+e_{1} & \text { if } h_{1}^{*}+e_{1}>0 \\
0 & \text { otherwise }\end{cases} \\
& \tilde{h}_{2}=\left\{\begin{array}{ll}
h_{2}^{*}+e_{2} & \text { if } h_{2}^{*}+e_{2}>0 \\
0 & \text { otherwise }
\end{array},\right.
\end{aligned}
$$

where we assume that $\left(e_{1}, e_{2}\right)$ follows a bivariate normal distribution with mean 0 and covariance $\Sigma$. This model can be considered a simultaneous Tobit model, where both variables are censored from below.

In order to calculate the new optimal hours (post-recession, see equation 4 in the text), we require expressions for the partial derivatives of the labor supply equations (equations B11 and B12) with respect to $w_{1}, w_{2}$, and $Y$. These functions are differentiated accordingly, with the help of Mathematica ${ }^{\circledR}$ (Wolfram Research, version 8 ). Since we specify a censored error distribution through estimation of a bivariate Tobit, the derivatives and hour predictions are adjusted following Muthen (1990), and then evaluated for each family. Only the averaged elasticity values are presented. 
For the case of single headed households, the corresponding quadratic utility form can be simplified to:

$U(Z)=a_{1}\left(L_{1}\right)+a_{3}(C)-\frac{1}{2} b_{11}\left(L_{1}\right)^{2}-\frac{1}{2} b_{33}(C)^{2}-b_{13} L_{1} C$

Where $L_{1}=T-h_{1} ;$ and, $C=w_{1} * h_{1}+Y$

In this case, the first order condition corresponding to the single household case becomes:

$\frac{\partial u}{\partial h_{1}}=a_{1}^{*}+a_{3}^{*} w_{1}-b_{11} h_{1}-b_{33} w_{1}\left(w_{1} h_{1}+Y\right)+b_{13}\left(2 w_{1} h_{1}+Y\right)=0$

In this case, the optimal hour supply can be directly obtain from solving equation (B16):

$h_{1}^{*}=\frac{a_{1}^{*}+a_{3}^{*} w_{1}-b_{33} w_{1} Y+b_{13} Y}{b_{11}+b_{33} w_{1}^{2}-2 b_{13} w_{1}}$

Finally, since observed hours $(\tilde{h})$ can differ from optimum hours due to stochastic errors, the corresponding model becomes:

$\tilde{h}_{1}= \begin{cases}h_{1}^{*}+e_{1} & \text { if } h_{1}^{*}+e_{1}>0 \\ 0 & \text { otherwise }\end{cases}$

Which can be estimated as a non-linear tobit model, that are censored from below. 
Appendix C: Maximum likelihood estimation results and dollar equivalent welfare changes as a function of pre-recession total income.

Table C.1. Maximum likelihood parameter estimates.

Panel (a): Married Family Households

\begin{tabular}{|c|c|c|c|c|c|c|c|c|c|c|c|}
\hline & $\begin{array}{l}\text { Full } \\
\text { Sample }\end{array}$ & Q1 & Q2 & Q3 & Q4 & Q5 & Q6 & Q7 & Q8 & Q9 & Q10 \\
\hline \multicolumn{12}{|l|}{ a1: Husband } \\
\hline Age & $\begin{array}{c}136.02 * \\
(3.40)\end{array}$ & $\begin{array}{c}164.13 * \\
(12.36)\end{array}$ & $\begin{array}{c}116.09 * \\
(10.52)\end{array}$ & $\begin{array}{l}133.75 * \\
(12.57)\end{array}$ & $\begin{array}{c}123.99 * \\
(10.42)\end{array}$ & $\begin{array}{c}151.28 * \\
(10.26)\end{array}$ & $\begin{array}{c}162.82 * \\
(8.88)\end{array}$ & $\begin{array}{c}162.71 * \\
(9.61)\end{array}$ & $\begin{array}{c}151.43^{*} \\
(8.69)\end{array}$ & $\begin{array}{c}164.25 * \\
(9.39)\end{array}$ & $\begin{array}{c}130.95 * \\
(8.81)\end{array}$ \\
\hline $\mathrm{Age}^{\wedge} 2$ & $\begin{array}{c}-172.55^{*} \\
(4.19)\end{array}$ & $\begin{array}{c}-227.24^{*} \\
(14.16)\end{array}$ & $\begin{array}{c}-161.15^{*} \\
(12.34)\end{array}$ & $\begin{array}{c}-176.51 * \\
(15.83)\end{array}$ & $\begin{array}{c}-162.47^{*} \\
(13.11)\end{array}$ & $\begin{array}{c}-195.56^{*} \\
(12.66)\end{array}$ & $\begin{array}{c}-206.78^{*} \\
(10.64)\end{array}$ & $\begin{array}{c}-203.11 * \\
(11.32)\end{array}$ & $\begin{array}{c}-186.56^{*} \\
(9.76)\end{array}$ & $\begin{array}{c}-198.48^{*} \\
(10.34)\end{array}$ & $\begin{array}{c}-159.07 * \\
(9.32)\end{array}$ \\
\hline Sex $($ Male=1 $)$ & $\begin{array}{c}176.27 * \\
(9.76)\end{array}$ & $\begin{array}{c}244.10 * \\
(33.37)\end{array}$ & $\begin{array}{l}99.82 * \\
(31.97)\end{array}$ & $\begin{array}{c}(15.980) \\
(33.88)\end{array}$ & $\begin{array}{c}74.15+ \\
(35.76)\end{array}$ & $\begin{array}{c}(50.510) \\
(44.87)\end{array}$ & $\begin{array}{c}(70.440) \\
(52.71)\end{array}$ & $\begin{array}{l}(6.060) \\
(60.87)\end{array}$ & $\begin{array}{c}(83.620) \\
(61.12)\end{array}$ & $\begin{array}{c}(151.980) \\
(109.91)\end{array}$ & $\begin{array}{l}(62.940) \\
(117.28)\end{array}$ \\
\hline \multicolumn{12}{|c|}{ Education (base=LTH) } \\
\hline High School & $\begin{array}{c}246.92 * \\
(11.17)\end{array}$ & $\begin{array}{c}328.60 * \\
(47.80)\end{array}$ & $\begin{array}{l}123.74 * \\
(37.74)\end{array}$ & $\begin{array}{c}(16.250) \\
(36.77)\end{array}$ & $\begin{array}{l}78.11+ \\
(38.31)\end{array}$ & $\begin{array}{c}(54.530) \\
(45.37)\end{array}$ & $\begin{array}{c}(77.190) \\
(53.51)\end{array}$ & $\begin{array}{c}(43.640) \\
(60.43)\end{array}$ & $\begin{array}{c}117.80+ \\
(58.74)\end{array}$ & $\begin{array}{c}(138.530) \\
(108.40)\end{array}$ & $\begin{array}{l}(23.700) \\
(112.96)\end{array}$ \\
\hline Some College & $\begin{array}{c}339.88 * \\
(13.54)\end{array}$ & $\begin{array}{c}420.20 * \\
(61.83)\end{array}$ & $\begin{array}{l}132.39 * \\
(48.34)\end{array}$ & $\begin{array}{c}(18.940) \\
(44.18)\end{array}$ & $\begin{array}{l}95.20+ \\
(42.28)\end{array}$ & $\begin{array}{l}96.61^{\wedge} \\
(49.81)\end{array}$ & $\begin{array}{c}(89.810) \\
(54.87)\end{array}$ & $\begin{array}{c}(29.740) \\
(62.85)\end{array}$ & $\begin{array}{c}(94.140) \\
(58.52)\end{array}$ & $\begin{array}{c}(163.180) \\
(107.66)\end{array}$ & $\begin{array}{l}(40.180) \\
(110.36)\end{array}$ \\
\hline College & $\begin{array}{c}495.10 * \\
(18.46)\end{array}$ & $\begin{array}{l}555.85^{*} \\
(131.60)\end{array}$ & $\begin{array}{c}(146.020) \\
(97.14)\end{array}$ & $\begin{array}{c}(40.590) \\
(73.67)\end{array}$ & $\begin{array}{c}(27.200) \\
(64.72)\end{array}$ & $\begin{array}{c}(109.240) \\
(70.57)\end{array}$ & $\begin{array}{c}(104.970) \\
(65.22)\end{array}$ & $\begin{array}{l}(2.820) \\
(69.09)\end{array}$ & $\begin{array}{c}153.31+ \\
(61.25)\end{array}$ & $\begin{array}{l}(72.200) \\
(109.07)\end{array}$ & $\begin{array}{c}(123.340) \\
(110.61)\end{array}$ \\
\hline \multicolumn{12}{|l|}{ Grad } \\
\hline Race (base=White) & $\begin{array}{c}-235.30 * \\
(9.57)\end{array}$ & $\begin{array}{c}-304.58^{*} \\
(47.51)\end{array}$ & $\begin{array}{c}-194.62 * \\
(36.85)\end{array}$ & $\begin{array}{c}-194.90 * \\
(35.07)\end{array}$ & $\begin{array}{c}-144.40^{*} \\
(31.12)\end{array}$ & $\begin{array}{c}-80.92+ \\
(32.67)\end{array}$ & $\begin{array}{c}-137.30 * \\
(34.10)\end{array}$ & $\begin{array}{l}-86.05 * \\
(28.93)\end{array}$ & $\begin{array}{l}-69.77+ \\
(32.21)\end{array}$ & $\begin{array}{l}-97.25 * \\
(36.17)\end{array}$ & $\begin{array}{c}-92.04+ \\
(37.69)\end{array}$ \\
\hline Black & $\begin{array}{c}-118.42 * \\
(10.63)\end{array}$ & $\begin{array}{c}121.10+ \\
(61.09)\end{array}$ & $\begin{array}{c}(66.710) \\
(54.25)\end{array}$ & $\begin{array}{c}(26.320) \\
(48.15)\end{array}$ & $\begin{array}{c}(35.310) \\
(41.17)\end{array}$ & $\begin{array}{c}(10.790) \\
(41.18)\end{array}$ & $\begin{array}{c}-74.28+ \\
(33.88)\end{array}$ & $\begin{array}{c}-128.61 * \\
(30.65)\end{array}$ & $\begin{array}{c}-100.69 * \\
(24.64)\end{array}$ & $\begin{array}{c}-100.40 * \\
(25.18)\end{array}$ & $\begin{array}{c}(32.190) \\
(23.03)\end{array}$ \\
\hline Other & $\begin{array}{c}-19.60 * \\
(7.41)\end{array}$ & $\begin{array}{c}221.56^{*} \\
(33.04)\end{array}$ & $\begin{array}{l}85.68 * \\
(30.63)\end{array}$ & $\begin{array}{l}(7.740) \\
(29.89)\end{array}$ & $\begin{array}{c}(28.130) \\
(27.57)\end{array}$ & $\begin{array}{l}(0.970) \\
(27.82)\end{array}$ & $\begin{array}{c}(31.130) \\
(26.85)\end{array}$ & $\begin{array}{c}(39.440) \\
(26.88)\end{array}$ & $\begin{array}{c}(18.290) \\
(25.82)\end{array}$ & $\begin{array}{c}(13.990) \\
(30.14)\end{array}$ & $\begin{array}{c}(35.030) \\
(29.80)\end{array}$ \\
\hline Hispanic & $\begin{array}{c}88.12 * \\
(9.59)\end{array}$ & $\begin{array}{l}120.89 * \\
(23.33)\end{array}$ & $\begin{array}{l}175.76^{*} \\
(25.44)\end{array}$ & $\begin{array}{l}195.20 * \\
(31.72)\end{array}$ & $\begin{array}{c}140.83 * \\
(30.62)\end{array}$ & $\begin{array}{l}65.00+ \\
(26.01)\end{array}$ & $\begin{array}{c}(29.590) \\
(21.50)\end{array}$ & $\begin{array}{l}53.81+ \\
(20.92)\end{array}$ & $\begin{array}{l}40.96^{*} \\
(15.82)\end{array}$ & $\begin{array}{l}48.53 * \\
(14.73)\end{array}$ & $\begin{array}{l}25.24+ \\
(11.19)\end{array}$ \\
\hline \#Children 0-5 & $\begin{array}{c}42.42 * \\
(5.97)\end{array}$ & $\begin{array}{l}(5.200) \\
(17.88)\end{array}$ & $\begin{array}{l}46.51 * \\
(18.03)\end{array}$ & $\begin{array}{l}62.38^{*} \\
(19.66)\end{array}$ & $\begin{array}{l}51.65+ \\
(20.08)\end{array}$ & $\begin{array}{l}39.04 * \\
(14.35)\end{array}$ & $\begin{array}{c}(17.270) \\
(13.79)\end{array}$ & $\begin{array}{l}28.82+ \\
(14.02)\end{array}$ & $\begin{array}{l}(9.540) \\
(10.92)\end{array}$ & $\begin{array}{l}20.63^{\wedge} \\
(10.91)\end{array}$ & $\begin{array}{c}(12.860) \\
(8.18)\end{array}$ \\
\hline \#Children 6-12 & $\begin{array}{c}56.44 * \\
(4.15)\end{array}$ & $\begin{array}{l}53.61+ \\
(22.51)\end{array}$ & $\begin{array}{c}111.47 * \\
(19.55)\end{array}$ & $\begin{array}{l}72.13 * \\
(17.31)\end{array}$ & $\begin{array}{l}46.25^{*} \\
(14.91)\end{array}$ & $\begin{array}{l}45.78 * \\
(14.15)\end{array}$ & $\begin{array}{l}33.54 * \\
(12.09)\end{array}$ & $\begin{array}{l}61.19 * \\
(11.33)\end{array}$ & $\begin{array}{c}56.08 * \\
(9.99)\end{array}$ & $\begin{array}{c}40.44 * \\
(9.63)\end{array}$ & $\begin{array}{c}59.14 * \\
(8.56)\end{array}$ \\
\hline
\end{tabular}


Full

\begin{tabular}{|c|c|c|c|c|c|c|c|c|c|c|c|}
\hline & $\begin{array}{l}\text { Full } \\
\text { Sample }\end{array}$ & Q1 & Q2 & Q3 & Q4 & Q5 & Q6 & Q7 & Q8 & Q9 & Q10 \\
\hline \multicolumn{12}{|l|}{ a2 :Wife } \\
\hline \multirow[t]{2}{*}{ Age } & $46.28^{*}$ & $56.36^{*}$ & $55.53 *$ & $39.03 *$ & $35.95^{*}$ & $66.57^{*}$ & $66.53^{*}$ & $48.60 *$ & $60.03 *$ & $55.54^{*}$ & $33.66 *$ \\
\hline & $(1.85)$ & $(11.25)$ & $(9.61)$ & (10.09) & $(8.64)$ & $(8.05)$ & $(8.25)$ & $(6.27)$ & $(6.16)$ & $(6.08)$ & $(4.61)$ \\
\hline \multirow[t]{2}{*}{$\mathrm{Age}^{\wedge} 2$} & $-63.20 *$ & $-81.49^{*}$ & $-82.36^{*}$ & $-59.61 *$ & $-56.44 *$ & $-92.79 *$ & $-92.54 *$ & $-65.54 *$ & $-77.23 *$ & $-72.66^{*}$ & $-46.05^{*}$ \\
\hline & $(2.24)$ & (13.19) & (11.53) & (13.06) & $(11.01)$ & $(10.48)$ & $(10.62)$ & $(7.76)$ & $(7.34)$ & $(7.22)$ & $(5.25)$ \\
\hline \multirow[t]{2}{*}{ Sex $($ Male $=1)$} & $211.79 *$ & $240.33^{*}$ & $264.48 *$ & $206.90 *$ & $141.21^{*}$ & $137.16^{*}$ & $(18.890)$ & $80.28^{\wedge}$ & $(68.760)$ & $(14.680)$ & $(50.460)$ \\
\hline & $(9.26)$ & $(34.78)$ & $(37.51)$ & $(45.45)$ & $(37.48)$ & $(45.41)$ & $(47.92)$ & $(45.30)$ & $(47.43)$ & $(70.25)$ & $(48.29)$ \\
\hline \multicolumn{12}{|c|}{ Education (base $=\mathrm{LTH})$} \\
\hline \multirow[t]{2}{*}{ High School } & $289.74 *$ & $383.81^{*}$ & $368.93 *$ & $274.70^{*}$ & $235.25^{*}$ & $189.55^{*}$ & $(62.450)$ & $87.16^{\wedge}$ & $111.89+$ & $(28.980)$ & $(33.020)$ \\
\hline & $(10.87)$ & $(47.02)$ & $(42.49)$ & $(48.78)$ & $(39.02)$ & $(46.16)$ & $(48.12)$ & $(44.91)$ & $(46.77)$ & $(69.21)$ & $(46.39)$ \\
\hline \multirow[t]{2}{*}{ Some College } & $344.14 *$ & $309.42 *$ & $316.15^{*}$ & $307.35^{*}$ & $267.28^{*}$ & $272.07 *$ & $141.72 *$ & $140.21 *$ & $133.05^{*}$ & $(68.800)$ & $(44.490)$ \\
\hline & $(12.46)$ & $(56.06)$ & $(46.87)$ & $(53.87)$ & $(41.25)$ & $(48.45)$ & $(48.96)$ & $(45.29)$ & $(46.71)$ & $(68.86)$ & $(45.41)$ \\
\hline \multirow[t]{2}{*}{ College } & $498.18 *$ & $271.32+$ & $274.51 *$ & $425.46^{*}$ & $242.39 *$ & $341.41 *$ & $234.82 *$ & $259.64 *$ & $238.39 *$ & $220.44^{*}$ & $173.74 *$ \\
\hline & (16.94) & $(111.32)$ & (94.79) & (75.12) & $(50.11)$ & $(56.33)$ & $(53.90)$ & $(48.30)$ & $(49.19)$ & $(70.62)$ & $(46.52)$ \\
\hline \multirow[t]{2}{*}{ Grad } & $152.80 *$ & $163.52 *$ & $166.58 *$ & $310.44 *$ & $224.73 *$ & $204.13 *$ & $220.00 *$ & $180.14^{*}$ & $166.60 *$ & $203.26^{*}$ & $200.48 *$ \\
\hline & $(10.20)$ & $(40.35)$ & $(37.79)$ & $(37.52)$ & $(29.11)$ & $(27.68)$ & $(29.72)$ & $(21.87)$ & $(22.91)$ & $(22.52)$ & $(21.50)$ \\
\hline \multicolumn{12}{|c|}{ Race (base $=$ White) } \\
\hline \multirow[t]{2}{*}{ Black } & $-87.18^{*}$ & $(74.480)$ & $(69.380)$ & $(75.620)$ & $-161.44^{*}$ & $-150.38^{*}$ & $-167.08^{*}$ & $-115.26^{*}$ & $-64.22 *$ & $(22.750)$ & (13.930) \\
\hline & $(7.85)$ & $(50.09)$ & $(49.25)$ & $(47.52)$ & $(35.42)$ & $(30.99)$ & $(29.05)$ & $(20.74)$ & $(15.93)$ & $(15.21)$ & $(11.23)$ \\
\hline \multirow[t]{2}{*}{ Other } & $-38.79 *$ & $-180.20 *$ & $-59.70^{\wedge}$ & $-55.79^{\wedge}$ & $-50.81+$ & $(23.610)$ & $(9.670)$ & $(25.520)$ & $90.05^{*}$ & $111.66^{*}$ & $61.53 *$ \\
\hline & $(6.40)$ & $(33.24)$ & $(31.31)$ & $(32.17)$ & $(24.80)$ & $(24.58)$ & $(22.57)$ & $(19.16)$ & $(17.87)$ & $(19.08)$ & $(14.37)$ \\
\hline \multirow[t]{2}{*}{ Hispanic } & $-313.04 *$ & $-410.00 *$ & $-497.39 *$ & $-492.58 *$ & $-403.87^{*}$ & $-369.83^{*}$ & $-367.10 *$ & $-293.60 *$ & $-254.97^{*}$ & $-249.78 *$ & $-192.15 *$ \\
\hline & $(12.31)$ & $(33.53)$ & $(31.48)$ & $(26.98)$ & $(26.86)$ & $(24.09)$ & $(25.18)$ & $(20.21)$ & $(18.15)$ & $(17.70)$ & $(12.51)$ \\
\hline \multirow[t]{2}{*}{ \#Children 0-5 } & $-169.52 *$ & $-144.59 *$ & $-220.03 *$ & $-211.62 *$ & $-212.40 *$ & $-164.23 *$ & $-197.82 *$ & $-157.12 *$ & $-158.87 *$ & $-177.49 *$ & $-134.96^{*}$ \\
\hline & $(7.24)$ & (18.23) & (18.93) & $(17.23)$ & $(16.63)$ & (13.39) & $(15.69)$ & $(12.26)$ & $(11.96)$ & $(12.82)$ & $(8.86)$ \\
\hline \multirow[t]{2}{*}{ \#Children 6-12 } & $-62.06^{*}$ & $(30.250)$ & $-50.56^{*}$ & $-56.11 *$ & $-46.83^{*}$ & $-81.73 *$ & $-49.96^{*}$ & $-46.12 *$ & $-63.02 *$ & $-76.02 *$ & $-64.78 *$ \\
\hline & (4.49) & (19.71) & (19.53) & (17.57) & $(13.16)$ & (12.24) & (11.01) & $(8.73)$ & $(8.31)$ & $(7.85)$ & $(6.03)$ \\
\hline \multirow[t]{2}{*}{ \#Children 13-17 } & $-767.00 *$ & $-2139.21^{*}$ & $-1612.34^{*}$ & $-893.23^{*}$ & $-630.59^{*}$ & $-971.19^{*}$ & $-697.01 *$ & $-687.50^{*}$ & $-926.14^{*}$ & $-720.68^{*}$ & $-384.53 *$ \\
\hline & $(39.48)$ & $(245.92)$ & $(199.53)$ & $(174.94)$ & $(143.34)$ & $(125.67)$ & $(126.91)$ & $(110.55)$ & $(123.46)$ & $(131.84)$ & $(105.31)$ \\
\hline \multirow[t]{2}{*}{ a3 } & $33.35^{*}$ & $287.80 *$ & $193.07 *$ & $116.29 *$ & $83.84 *$ & $69.33^{*}$ & $56.55^{*}$ & $37.84^{*}$ & $28.47 *$ & $19.09 *$ & $12.85^{*}$ \\
\hline & $(0.71)$ & $(10.91)$ & $(6.36)$ & $(5.26)$ & $(3.41)$ & $(2.84)$ & $(2.46)$ & $(1.67)$ & $(1.41)$ & $(0.94)$ & $(0.66)$ \\
\hline \multirow[t]{2}{*}{$\mathrm{b} 12$} & $-0.32 *$ & $-0.59 *$ & $-0.67 *$ & $-0.66^{*}$ & $-0.50 *$ & $-0.36^{*}$ & $-0.29 *$ & $-0.29 *$ & $-0.23^{*}$ & $-0.21 *$ & $-0.14^{*}$ \\
\hline & $(0.02)$ & $(0.05)$ & $(0.05)$ & $(0.06)$ & $(0.06)$ & $(0.04)$ & $(0.04)$ & $(0.03)$ & $(0.03)$ & $(0.02)$ & $(0.01)$ \\
\hline \multirow[t]{2}{*}{ b13 } & $-.005^{*}$ & $-.028^{*}$ & $-.018^{*}$ & $-.014^{*}$ & $-.0098^{*}$ & $-.0089 *$ & $-.0069 *$ & $-.0059 *$ & $-.0041 *$ & $-.0034 *$ & $-.0019 *$ \\
\hline & & & & & - C2 - & & & & & & \\
\hline
\end{tabular}




\begin{tabular}{|c|c|c|c|c|c|c|c|c|c|c|c|}
\hline & $\begin{array}{l}\text { Full } \\
\text { Sample }\end{array}$ & Q1 & Q2 & Q3 & Q4 & Q5 & Q6 & Q7 & Q8 & Q9 & Q10 \\
\hline & $(0.0001)$ & $(0.0016)$ & $(0.0010)$ & $(0.0006)$ & $(0.0005)$ & $(0.0004)$ & $(0.0003)$ & $(0.0002)$ & $(0.0002)$ & $(0.0002)$ & $(0.0001)$ \\
\hline \multirow[t]{2}{*}{$\mathrm{b} 22$} & $0.62 *$ & $0.95 *$ & $1.04 *$ & $1.01 *$ & $0.81 *$ & $0.73^{*}$ & $0.70^{*}$ & $0.53 *$ & $0.47^{*}$ & $0.43^{*}$ & $0.34 *$ \\
\hline & $(0.02)$ & $(0.05)$ & $(0.05)$ & $(0.05)$ & $(0.05)$ & $(0.04)$ & $(0.04)$ & $(0.03)$ & $(0.03)$ & $(0.03)$ & $(0.02)$ \\
\hline \multirow[t]{2}{*}{ b23 } & $-.0031 *$ & -0.00046 & $-.0045^{*}$ & $-.0046^{*}$ & $-.0036^{*}$ & $-.0032 *$ & $-.0032 *$ & $-.0027 *$ & $-.0022 *$ & $-.0021 *$ & $-.0012 *$ \\
\hline & $(0.0001)$ & $(0.0016)$ & $(0.0009)$ & $(0.0006)$ & $(0.0004)$ & $(0.0004)$ & $(0.0003)$ & $(0.0002)$ & $(0.0002)$ & $(0.0001)$ & $(0.0001)$ \\
\hline \multirow[t]{2}{*}{ b33 } & $.000032 *$ & $.0037^{*}$ & $.0015^{*}$ & $.00065^{*}$ & $.00038 *$ & $.00031 *$ & $.0002 *$ & $.000086^{*}$ & $.000046^{*}$ & $.000013 *$ & $2.8 \mathrm{e}-06^{*}$ \\
\hline & $(0.000002)$ & $(0.000180)$ & $(0.000078)$ & $(0.000061)$ & $(0.000030)$ & $(0.000021)$ & $(0.000013)$ & $(0.000007)$ & $(0.000004)$ & $(0.000002)$ & $(0.000001)$ \\
\hline \multirow[t]{2}{*}{ drho } & $-0.17^{*}$ & $-0.12 *$ & $-0.22 *$ & $-0.27^{*}$ & $-0.23 *$ & $-0.09^{\wedge}$ & -0.06 & $-0.12^{*}$ & $-0.08^{*}$ & $-0.11^{*}$ & $-0.04+$ \\
\hline & $(0.02)$ & $(0.02)$ & $(0.03)$ & $(0.06)$ & $(0.05)$ & $(0.05)$ & $(0.04)$ & $(0.04)$ & $(0.03)$ & $(0.03)$ & $(0.02)$ \\
\hline \multirow[t]{2}{*}{ s1 } & $852.46^{*}$ & $901.18 *$ & $876.86^{*}$ & $845.04 *$ & $821.95 *$ & $803.71 *$ & $799.11 *$ & $793.91 *$ & $780.05 *$ & $774.53 *$ & $780.43 *$ \\
\hline & (1.69) & $(6.21)$ & $(5.78)$ & $(5.76)$ & $(5.44)$ & $(4.97)$ & (4.99) & $(4.99)$ & (4.73) & $(4.67)$ & $(4.56)$ \\
\hline \multirow[t]{2}{*}{ s2 } & $1107.79 *$ & $1296.91 *$ & $1160.69 *$ & $1096.43 *$ & $1051.98 *$ & $1022.44^{*}$ & $1010.48 *$ & $1026.30^{*}$ & $1038.43^{*}$ & $1050.13^{*}$ & $1105.06^{*}$ \\
\hline & (2.13) & (7.79) & $(6.91)$ & $(6.31)$ & $(6.15)$ & $(5.59)$ & $(5.57)$ & $(5.49)$ & (5.44) & $(5.33)$ & $(5.47)$ \\
\hline LL & $-5.237 \mathrm{E}+08$ & $-4.678 \mathrm{E}+07$ & $-4.996 \mathrm{E}+07$ & $-5.164 \mathrm{E}+07$ & $-5.275 \mathrm{E}+07$ & $-5.309 \mathrm{E}+07$ & $-5.354 \mathrm{E}+07$ & $-5.337 \mathrm{E}+07$ & $-5.382 \mathrm{E}+07$ & $-5.310 \mathrm{E}+07$ & $-5.297 \mathrm{E}+07$ \\
\hline $\mathrm{N}$ & 400803 & 35594 & 39483 & 40520 & 40380 & 40698 & 41026 & 40941 & 40565 & 40233 & 41146 \\
\hline
\end{tabular}

Standard errors in parentheses

$\wedge \mathrm{p}<0.1,+\mathrm{p}<0.05, * \mathrm{p}<0.01$ 
Panel (b): Single Men.

\begin{tabular}{|c|c|c|c|c|c|c|c|c|c|c|c|}
\hline & $\begin{array}{c}\text { Full } \\
\text { Sample }\end{array}$ & Q1 & Q2 & Q3 & Q4 & Q5 & Q6 & Q7 & Q8 & Q9 & Q10 \\
\hline \multicolumn{12}{|l|}{ a1 } \\
\hline \multirow[t]{2}{*}{ Age } & $144.48 *$ & -38.20 & -3.82 & $109.01 *$ & $78.06^{*}$ & $166.13^{*}$ & $167.56^{*}$ & $134.30^{*}$ & $192.29 *$ & $135.33^{*}$ & $148.08 *$ \\
\hline & $(9.53)$ & $(71.26)$ & $(51.79)$ & $(27.54)$ & $(23.52)$ & $(34.80)$ & $(37.83)$ & $(28.22)$ & $(24.72)$ & $(24.17)$ & $(27.58)$ \\
\hline \multirow[t]{2}{*}{$\operatorname{Age}^{\wedge} 2$} & $-220.04 *$ & -22.78 & -57.83 & $-190.60 *$ & $-149.63^{*}$ & $-248.38^{*}$ & $-255.00^{*}$ & $-201.94 *$ & $-250.13^{*}$ & $-186.27^{*}$ & $-202.12 *$ \\
\hline & $(11.72)$ & $(81.02)$ & $(59.05)$ & $(34.40)$ & $(27.96)$ & $(40.38)$ & $(47.31)$ & $(34.39)$ & $(29.49)$ & $(27.01)$ & $(29.80)$ \\
\hline Married & $563.26^{*}$ & $1009.43+$ & 181.30 & $612.56^{*}$ & $512.20 *$ & $859.34 *$ & $499.58+$ & $456.98 *$ & $312.62 *$ & $236.34 *$ & $516.82 *$ \\
\hline (Spouse absent) & $(63.73)$ & $(481.91)$ & $(178.83)$ & $(224.34)$ & $(153.86)$ & $(240.98)$ & $(225.31)$ & $(143.06)$ & $(102.97)$ & $(80.12)$ & $(95.77)$ \\
\hline \multicolumn{12}{|c|}{ Education $($ base $=\mathrm{LTH})$} \\
\hline \multirow[t]{2}{*}{ High School } & $510.11 *$ & -77.19 & $458.71+$ & $354.48+$ & 69.96 & -160.02 & -65.95 & -322.08 & -200.91 & 374.75 & 266.54 \\
\hline & $(44.08)$ & $(280.59)$ & $(187.91)$ & $(171.34)$ & $(155.13)$ & $(291.81)$ & $(401.28)$ & $(265.56)$ & $(379.43)$ & $(436.88)$ & $(467.66)$ \\
\hline \multirow[t]{2}{*}{ Some College } & $706.30^{*}$ & -245.73 & $537.75+$ & $567.38^{*}$ & 51.16 & -177.64 & 295.13 & $-437.68^{\wedge}$ & -262.88 & 494.28 & $661.64^{\wedge}$ \\
\hline & $(51.99)$ & $(491.12)$ & $(253.85)$ & $(206.99)$ & $(156.25)$ & $(304.83)$ & $(392.83)$ & $(263.25)$ & $(390.85)$ & $(428.40)$ & $(348.83)$ \\
\hline \multirow[t]{2}{*}{ College } & $1076.30 *$ & 887.14 & 447.72 & 448.76 & 308.25 & 404.19 & 495.47 & -294.28 & -308.73 & 4.99 & 93.92 \\
\hline & $(76.23)$ & $(1034.73)$ & $(442.57)$ & $(297.31)$ & (198.59) & $(326.73)$ & $(407.72)$ & $(252.17)$ & $(375.90)$ & $(415.90)$ & $(269.83)$ \\
\hline \multirow[t]{2}{*}{ Grad } & $1544.81 *$ & -2907.40 & -465.20 & -220.44 & -257.89 & -868.67 & 572.34 & -45.13 & -102.80 & 169.54 & 299.32 \\
\hline & $(121.90)$ & $(2147.43)$ & $(1061.87)$ & $(818.30)$ & (396.17) & $(539.70)$ & $(545.99)$ & $(277.12)$ & $(372.25)$ & $(418.43)$ & $(266.90)$ \\
\hline \multicolumn{12}{|c|}{ Race (base $=$ White) } \\
\hline \multirow[t]{2}{*}{ Black } & $-401.04 *$ & 211.85 & $-602.95^{*}$ & $-463.00 *$ & $-307.00^{*}$ & 80.87 & -200.81 & $-236.86^{*}$ & 22.52 & -55.11 & $-279.12 *$ \\
\hline & $(39.68)$ & $(264.90)$ & $(199.10)$ & (139.18) & $(103.07)$ & $(177.25)$ & $(139.15)$ & $(91.47)$ & $(82.91)$ & $(80.60)$ & $(103.00)$ \\
\hline \multirow[t]{2}{*}{ Other } & $-308.07^{*}$ & -10.15 & $-486.51^{\wedge}$ & -108.42 & -179.56 & -0.90 & $-386.54^{\wedge}$ & -86.74 & $-166.19+$ & -14.94 & 20.66 \\
\hline & $(58.48)$ & $(412.47)$ & $(275.39)$ & $(179.03)$ & $(159.71)$ & $(281.75)$ & $(201.92)$ & $(125.29)$ & $(73.87)$ & $(92.24)$ & $(100.60)$ \\
\hline \multirow[t]{2}{*}{ Hispanic } & $180.10^{*}$ & $961.54+$ & $539.01 *$ & -10.28 & 175.72 & 121.00 & $353.64+$ & 85.70 & -64.04 & $-163.97^{\wedge}$ & 84.66 \\
\hline & $(39.00)$ & $(402.40)$ & $(181.80)$ & $(125.52)$ & $(120.71)$ & (148.33) & $(164.32)$ & $(88.83)$ & $(75.41)$ & $(86.57)$ & (109.49) \\
\hline \multirow[t]{2}{*}{ \#Children 0-5 } & 63.64 & 184.25 & 177.78 & 207.97 & 192.05 & $-450.74+$ & 163.23 & $274.79^{\wedge}$ & 105.04 & -108.94 & -44.30 \\
\hline & $(66.46)$ & $(308.47)$ & $(246.83)$ & (177.67) & (197.90) & $(219.56)$ & $(198.96)$ & $(146.28)$ & $(116.67)$ & $(121.27)$ & $(180.32)$ \\
\hline \multirow[t]{2}{*}{ \#Children 6-12 } & 57.41 & 240.00 & 25.78 & 113.45 & -39.30 & 383.35 & 72.63 & $152.24^{\wedge}$ & 24.37 & 58.26 & $151.99+$ \\
\hline & (43.89) & $(315.78)$ & $(186.25)$ & $(127.52)$ & (106.24) & $(246.53)$ & $(132.42)$ & $(88.85)$ & $(54.49)$ & $(72.53)$ & $(63.39)$ \\
\hline \multirow[t]{2}{*}{ \#Children 13-17 } & $330.99 *$ & 171.86 & $543.66+$ & $514.21+$ & $332.03+$ & 284.15 & $382.02+$ & $354.98 *$ & $163.55+$ & $141.58+$ & $208.99 *$ \\
\hline & $(51.39)$ & $(365.31)$ & $(277.04)$ & (202.09) & $(145.21)$ & (189.90) & $(157.43)$ & (99.73) & $(66.56)$ & $(67.61)$ & $(72.53)$ \\
\hline \multirow[t]{2}{*}{ _cons } & $-1522.66^{*}$ & -1695.72 & -218.17 & $-1437.46+$ & -149.96 & -1253.93 & -1030.78 & 150.58 & $-1393.13+$ & 19.06 & -415.96 \\
\hline & $(202.48)$ & $(1692.51)$ & $(1102.17)$ & $(594.88)$ & (499.99) & $(839.37)$ & $(848.59)$ & $(579.54)$ & $(555.15)$ & $(672.37)$ & $(661.98)$ \\
\hline
\end{tabular}




\begin{tabular}{|c|c|c|c|c|c|c|c|c|c|c|c|}
\hline $\mathrm{a} 2$ & $\begin{array}{c}280.78^{*} \\
(24.94)\end{array}$ & $\begin{array}{l}1504.80 * \\
(543.59)\end{array}$ & $\begin{array}{c}781.61 * \\
(189.15)\end{array}$ & $\begin{array}{l}478.15^{*} \\
(102.78)\end{array}$ & $\begin{array}{c}302.06^{*} \\
(44.74)\end{array}$ & $\begin{array}{l}352.85 * \\
(87.64)\end{array}$ & $\begin{array}{c}279.41 * \\
(71.63)\end{array}$ & $\begin{array}{l}154.56^{*} \\
(32.54)\end{array}$ & $\begin{array}{l}75.63 * \\
(20.98)\end{array}$ & $\begin{array}{l}69.35^{*} \\
(8.28)\end{array}$ & $\begin{array}{l}64.70 * \\
(6.55)\end{array}$ \\
\hline b12 & $\begin{array}{l}-.056^{*} \\
(0.006)\end{array}$ & $\begin{array}{c}-.2^{\wedge} \\
(0.120)\end{array}$ & $\begin{array}{c}-.1+ \\
(0.045)\end{array}$ & $\begin{array}{l}-.063+ \\
(0.026)\end{array}$ & $\begin{array}{l}-.038^{*} \\
(0.011)\end{array}$ & $\begin{array}{l}-.066^{*} \\
(0.022)\end{array}$ & $\begin{array}{c}-.06^{*} \\
(0.018)\end{array}$ & $\begin{array}{l}-.033^{*} \\
(0.008)\end{array}$ & $\begin{array}{l}-.014 * \\
(0.005)\end{array}$ & $\begin{array}{l}-.018^{*} \\
(0.002)\end{array}$ & $\begin{array}{l}-.017^{*} \\
(0.002)\end{array}$ \\
\hline $\mathrm{b} 22$ & $\begin{array}{c}.00026^{*} \\
(0.00003)\end{array}$ & $\begin{array}{c}.013 * \\
(0.00210)\end{array}$ & $\begin{array}{c}.0053 * \\
(0.00048)\end{array}$ & $\begin{array}{c}.0029 * \\
(0.00026)\end{array}$ & $\begin{array}{c}.0015^{*} \\
(0.00016)\end{array}$ & $\begin{array}{c}.00088^{*} \\
(0.00016)\end{array}$ & $\begin{array}{c}.0003 * \\
(0.00009)\end{array}$ & $\begin{array}{c}.00017 * \\
(0.00004)\end{array}$ & $\begin{array}{c}.00009 * \\
(0.00002)\end{array}$ & $\begin{array}{c}0.000 \\
(0.00001)\end{array}$ & $\begin{array}{c}-.000044 * \\
(0.00001)\end{array}$ \\
\hline s1 & $\begin{array}{c}931.52^{*} \\
(5.36) \\
\end{array}$ & $\begin{array}{l}916.60^{*} \\
(18.54)\end{array}$ & $\begin{array}{l}890.32 * \\
(15.05) \\
\end{array}$ & $\begin{array}{l}924.52 * \\
(14.15) \\
\end{array}$ & $\begin{array}{l}931.21^{*} \\
(12.76) \\
\end{array}$ & $\begin{array}{l}920.66^{*} \\
(14.48) \\
\end{array}$ & $\begin{array}{l}903.62^{*} \\
(12.63) \\
\end{array}$ & $\begin{array}{l}910.78^{*} \\
(10.98)\end{array}$ & $\begin{array}{l}890.02 * \\
(14.54)\end{array}$ & $\begin{array}{c}837.94 * \\
(9.81) \\
\end{array}$ & $\begin{array}{c}859.86^{*} \\
(10.03) \\
\end{array}$ \\
\hline 11 & $-7.97 \mathrm{E}+07$ & $-4.84 \mathrm{E}+06$ & $-6.94 \mathrm{E}+06$ & $-7.93 \mathrm{E}+06$ & $-8.65 \mathrm{E}+06$ & $-8.67 \mathrm{E}+06$ & $-8.40 \mathrm{E}+06$ & $-8.44 \mathrm{E}+06$ & $-8.57 \mathrm{E}+06$ & $-8.59 \mathrm{E}+06$ & $-8.22 \mathrm{E}+06$ \\
\hline $\mathrm{N}$ & 97,808 & 7,061 & 8,573 & 10,542 & 10,281 & 10,320 & 10,403 & 10,189 & 10,249 & 10,265 & 9,925 \\
\hline
\end{tabular}


Panel (c): Single Women.

\begin{tabular}{|c|c|c|c|c|c|c|c|c|c|c|c|}
\hline & $\begin{array}{c}\text { Full } \\
\text { Sample }\end{array}$ & Q1 & Q2 & Q3 & Q4 & Q5 & Q6 & Q7 & Q8 & Q9 & Q10 \\
\hline \multicolumn{12}{|l|}{ a1 } \\
\hline Age & $\begin{array}{c}153.02 * \\
(7.28)\end{array}$ & $\begin{array}{c}53.37 \\
(52.19)\end{array}$ & $\begin{array}{c}30.65 \\
(37.65)\end{array}$ & $\begin{array}{l}109.90 * \\
(31.38)\end{array}$ & $\begin{array}{c}116.79 * \\
(25.80)\end{array}$ & $\begin{array}{l}145.63 * \\
(24.90)\end{array}$ & $\begin{array}{l}93.34 * \\
(18.30)\end{array}$ & $\begin{array}{c}86.05^{*} \\
(15.76)\end{array}$ & $\begin{array}{c}144.69 * \\
(18.40)\end{array}$ & $\begin{array}{c}135.24 * \\
(19.40)\end{array}$ & $\begin{array}{c}205.06^{*} \\
(18.73)\end{array}$ \\
\hline $\operatorname{Age}^{\wedge} 2$ & $\begin{array}{c}-208.58^{*} \\
(8.50)\end{array}$ & $\begin{array}{c}-124.53+ \\
(60.57)\end{array}$ & $\begin{array}{c}-91.90+ \\
(43.15)\end{array}$ & $\begin{array}{c}-180.25^{*} \\
(35.92)\end{array}$ & $\begin{array}{c}-184.85 * \\
(30.07)\end{array}$ & $\begin{array}{c}-203.89 * \\
(28.94)\end{array}$ & $\begin{array}{c}-144.04 * \\
(21.12)\end{array}$ & $\begin{array}{c}-130.76^{*} \\
(18.39)\end{array}$ & $\begin{array}{c}-199.59 * \\
(20.33)\end{array}$ & $\begin{array}{c}-179.49 * \\
(21.59)\end{array}$ & $\begin{array}{c}-250.74 * \\
(20.10)\end{array}$ \\
\hline Married (Spouse absent) & $\begin{array}{c}-103.21 * \\
(39.56)\end{array}$ & $\begin{array}{c}-93.52 \\
(278.62)\end{array}$ & $\begin{array}{c}119.71 \\
(206.13)\end{array}$ & $\begin{array}{c}33.08 \\
(189.14)\end{array}$ & $\begin{array}{c}-567.96 * \\
(175.41)\end{array}$ & $\begin{array}{l}-209.71 \\
(153.61)\end{array}$ & $\begin{array}{l}-353.41^{*} \\
(122.18)\end{array}$ & $\begin{array}{l}-117.69 \\
(100.50)\end{array}$ & $\begin{array}{l}-132.74 \\
(100.37)\end{array}$ & $\begin{array}{l}-75.14 \\
(72.75)\end{array}$ & $\begin{array}{c}5.42 \\
(85.51)\end{array}$ \\
\hline \multicolumn{12}{|l|}{ Education $($ base $=\mathrm{LTH})$} \\
\hline High School & $\begin{array}{c}602.02 * \\
(31.32)\end{array}$ & $\begin{array}{l}770.14 * \\
(192.75)\end{array}$ & $\begin{array}{c}297.70+ \\
(146.89)\end{array}$ & $\begin{array}{l}610.78^{*} \\
(181.18)\end{array}$ & $\begin{array}{c}277.41 \\
(177.55)\end{array}$ & $\begin{array}{l}261.22^{\wedge} \\
(158.05)\end{array}$ & $\begin{array}{c}93.09 \\
(217.19)\end{array}$ & $\begin{array}{c}287.21 \\
(184.59)\end{array}$ & $\begin{array}{c}-70.35 \\
(246.04)\end{array}$ & $\begin{array}{c}-43.19 \\
(240.75)\end{array}$ & $\begin{array}{c}364.32 \\
(355.24)\end{array}$ \\
\hline Some College & $\begin{array}{l}791.92 * \\
(36.12)\end{array}$ & $\begin{array}{l}1019.09 * \\
(271.45)\end{array}$ & $\begin{array}{c}562.57 * \\
(179.89)\end{array}$ & $\begin{array}{l}694.34 * \\
(190.86)\end{array}$ & $\begin{array}{c}181.48 \\
(179.07)\end{array}$ & $\begin{array}{l}285.09^{\wedge} \\
(156.11)\end{array}$ & $\begin{array}{c}118.06 \\
(212.63)\end{array}$ & $\begin{array}{c}191.37 \\
(180.89)\end{array}$ & $\begin{array}{c}-64.01 \\
(240.87)\end{array}$ & $\begin{array}{c}-62.95 \\
(231.04)\end{array}$ & $\begin{array}{c}365.69 \\
(327.44)\end{array}$ \\
\hline College & $\begin{array}{c}1127.03 * \\
(48.15)\end{array}$ & $\begin{array}{l}1160.60 * \\
(435.91)\end{array}$ & $\begin{array}{l}698.30 * \\
(249.26)\end{array}$ & $\begin{array}{l}405.12^{\wedge} \\
(236.71)\end{array}$ & $\begin{array}{c}336.71 \\
(209.31)\end{array}$ & $\begin{array}{l}528.23 * \\
(171.67)\end{array}$ & $\begin{array}{c}179.79 \\
(211.36)\end{array}$ & $\begin{array}{c}284.14 \\
(179.85)\end{array}$ & $\begin{array}{l}-116.69 \\
(239.43)\end{array}$ & $\begin{array}{l}-206.97 \\
(228.48)\end{array}$ & $\begin{array}{c}408.11 \\
(309.88)\end{array}$ \\
\hline Grad & $\begin{array}{c}1548.77 * \\
(70.06)\end{array}$ & $\begin{array}{c}1457.09 \\
(1067.11)\end{array}$ & $\begin{array}{c}831.94 \\
(642.74)\end{array}$ & $\begin{array}{l}868.22^{\wedge} \\
(523.24)\end{array}$ & $\begin{array}{l}508.99^{\wedge} \\
(279.35)\end{array}$ & $\begin{array}{l}567.91+ \\
(236.85)\end{array}$ & $\begin{array}{c}367.76 \\
(231.44)\end{array}$ & $\begin{array}{l}439.31+ \\
(188.38)\end{array}$ & $\begin{array}{c}-3.00 \\
(243.75)\end{array}$ & $\begin{array}{l}-114.77 \\
(229.61)\end{array}$ & $\begin{array}{l}561.51^{\wedge} \\
(309.39)\end{array}$ \\
\hline \multicolumn{12}{|l|}{ Race (base $=$ White) } \\
\hline Black & $\begin{array}{c}-167.36^{*} \\
(19.46)\end{array}$ & $\begin{array}{l}241.60^{\wedge} \\
(143.95)\end{array}$ & $\begin{array}{c}-97.18 \\
(104.29)\end{array}$ & $\begin{array}{c}-3.98 \\
(99.09)\end{array}$ & $\begin{array}{l}-68.32 \\
(76.71)\end{array}$ & $\begin{array}{c}27.53 \\
(71.34)\end{array}$ & $\begin{array}{c}82.69 \\
(60.09)\end{array}$ & $\begin{array}{c}60.05 \\
(47.09)\end{array}$ & $\begin{array}{l}-98.99 \\
(63.82)\end{array}$ & $\begin{array}{c}44.53 \\
(48.70)\end{array}$ & $\begin{array}{l}-50.07 \\
(56.92)\end{array}$ \\
\hline Other & $\begin{array}{l}-62.70 \\
(38.18)\end{array}$ & $\begin{array}{l}657.30+ \\
(265.49)\end{array}$ & $\begin{array}{c}-42.56 \\
(203.22)\end{array}$ & $\begin{array}{c}-38.37 \\
(181.23)\end{array}$ & $\begin{array}{c}-25.87 \\
(239.72)\end{array}$ & $\begin{array}{l}445.24+ \\
(182.33)\end{array}$ & $\begin{array}{c}-30.65 \\
(121.98)\end{array}$ & $\begin{array}{l}133.96^{\wedge} \\
(81.08)\end{array}$ & $\begin{array}{c}2.33 \\
(79.56)\end{array}$ & $\begin{array}{c}27.80 \\
(62.11)\end{array}$ & $\begin{array}{l}140.78^{\wedge} \\
(83.31)\end{array}$ \\
\hline Hispanic & $\begin{array}{l}179.04 * \\
(26.61)\end{array}$ & $\begin{array}{l}905.85 * \\
(224.13)\end{array}$ & $\begin{array}{c}618.03 * \\
(149.51)\end{array}$ & $\begin{array}{l}431.79 * \\
(137.97)\end{array}$ & $\begin{array}{l}375.61 * \\
(118.41)\end{array}$ & $\begin{array}{l}259.53+ \\
(102.20)\end{array}$ & $\begin{array}{c}186.09+ \\
(82.70)\end{array}$ & $\begin{array}{c}178.55^{*} \\
(63.97)\end{array}$ & $\begin{array}{l}-23.52 \\
(76.89)\end{array}$ & $\begin{array}{c}12.14 \\
(70.46)\end{array}$ & $\begin{array}{c}240.82 * \\
(77.66)\end{array}$ \\
\hline \#Children 0-5 & $\begin{array}{c}-211.56^{*} \\
(20.38)\end{array}$ & $\begin{array}{c}-240.55+ \\
(109.32)\end{array}$ & $\begin{array}{c}-80.60 \\
(110.70)\end{array}$ & $\begin{array}{c}-33.40 \\
(107.93)\end{array}$ & $\begin{array}{c}-180.97+ \\
(88.07)\end{array}$ & $\begin{array}{c}-222.28+ \\
(90.91)\end{array}$ & $\begin{array}{c}-226.39 * \\
(75.21)\end{array}$ & $\begin{array}{c}-275.82 * \\
(83.85)\end{array}$ & $\begin{array}{c}-184.38+ \\
(91.30)\end{array}$ & $\begin{array}{c}-249.97 * \\
(85.61)\end{array}$ & $\begin{array}{c}-166.17+ \\
(71.59)\end{array}$ \\
\hline \#Children 6-12 & $\begin{array}{c}-111.37 * \\
(13.03)\end{array}$ & $\begin{array}{c}101.97 \\
(80.17)\end{array}$ & $\begin{array}{l}-54.93 \\
(64.11)\end{array}$ & $\begin{array}{c}83.95 \\
(77.64)\end{array}$ & $\begin{array}{l}-47.57 \\
(73.28)\end{array}$ & $\begin{array}{c}-11.24 \\
(51.34)\end{array}$ & $\begin{array}{c}-100.83+ \\
(40.50)\end{array}$ & $\begin{array}{c}-104.89 * \\
(35.25)\end{array}$ & $\begin{array}{c}-234.70^{*} \\
(40.98)\end{array}$ & $\begin{array}{c}-255.79 * \\
(39.89)\end{array}$ & $\begin{array}{c}-176.43 * \\
(35.69)\end{array}$ \\
\hline \#Children 13-17 & $\begin{array}{c}31.27+ \\
(15.25)\end{array}$ & $\begin{array}{l}499.96^{*} \\
(129.70)\end{array}$ & $\begin{array}{c}417.65^{*} \\
(91.98)\end{array}$ & $\begin{array}{c}298.84 * \\
(77.77)\end{array}$ & $\begin{array}{c}243.71 * \\
(70.44)\end{array}$ & $\begin{array}{c}66.00 \\
(52.50)\end{array}$ & $\begin{array}{l}81.05^{\wedge} \\
(43.61)\end{array}$ & $\begin{array}{c}20.81 \\
(36.84)\end{array}$ & $\begin{array}{l}-51.31 \\
(38.90)\end{array}$ & $\begin{array}{c}-0.25 \\
(32.35)\end{array}$ & $\begin{array}{c}-69.23+ \\
(29.52)\end{array}$ \\
\hline _cons & $\begin{array}{c}-2290.39 * \\
(159.75) \\
\end{array}$ & $\begin{array}{c}-2983.99 * \\
(1145.00) \\
\end{array}$ & $\begin{array}{l}-693.46 \\
(825.77) \\
\end{array}$ & $\begin{array}{c}-1652.95+ \\
(700.46) \\
\end{array}$ & $\begin{array}{l}-972.28^{\wedge} \\
(551.13)\end{array}$ & $\begin{array}{c}-1568.96^{*} \\
(534.14) \\
\end{array}$ & $\begin{array}{c}-15.34 \\
(420.88) \\
\end{array}$ & $\begin{array}{c}209.92 \\
(370.07) \\
\end{array}$ & $\begin{array}{l}-463.39 \\
(462.21) \\
\end{array}$ & $\begin{array}{l}-262.58 \\
(470.91) \\
\end{array}$ & $\begin{array}{c}-2342.57 * \\
(510.76)\end{array}$ \\
\hline
\end{tabular}




\begin{tabular}{|c|c|c|c|c|c|c|c|c|c|c|c|}
\hline $\mathrm{a} 2$ & $\begin{array}{c}210.84^{*} \\
(11.17)\end{array}$ & $\begin{array}{l}1395.23 * \\
(181.39)\end{array}$ & $\begin{array}{l}770.94 * \\
(91.36)\end{array}$ & $\begin{array}{l}499.68^{*} \\
(50.37)\end{array}$ & $\begin{array}{c}332.18^{*} \\
(34.48)\end{array}$ & $\begin{array}{c}242.70 * \\
(35.88)\end{array}$ & $\begin{array}{l}175.45^{*} \\
(19.16)\end{array}$ & $\begin{array}{c}108.26^{*} \\
(9.92)\end{array}$ & $\begin{array}{c}102.33^{*} \\
(9.00)\end{array}$ & $\begin{array}{l}55.28^{*} \\
(7.35)\end{array}$ & $\begin{array}{l}49.86^{*} \\
(4.68)\end{array}$ \\
\hline b12 & $\begin{array}{c}-.04 * \\
(0.003)\end{array}$ & $\begin{array}{c}-.24 * \\
(0.049)\end{array}$ & $\begin{array}{l}-.14^{*} \\
(0.025)\end{array}$ & $\begin{array}{c}-.1^{*} \\
(0.015)\end{array}$ & $\begin{array}{l}-.065^{*} \\
(0.010)\end{array}$ & $\begin{array}{l}-.048^{*} \\
(0.011)\end{array}$ & $\begin{array}{l}-.035^{*} \\
(0.005)\end{array}$ & $\begin{array}{l}-.022 * \\
(0.003)\end{array}$ & $\begin{array}{l}-.021^{*} \\
(0.002)\end{array}$ & $\begin{array}{l}-.011^{*} \\
(0.002)\end{array}$ & $\begin{array}{l}-.013^{*} \\
(0.001)\end{array}$ \\
\hline $\mathrm{b} 22$ & $\begin{array}{c}.00049 * \\
(0.00003)\end{array}$ & $\begin{array}{c}.018^{*} \\
(0.00190)\end{array}$ & $\begin{array}{c}.0046^{*} \\
(0.00045)\end{array}$ & $\begin{array}{c}.002 * \\
(0.00032)\end{array}$ & $\begin{array}{c}.0011^{*} \\
(0.00018)\end{array}$ & $\begin{array}{c}.00065^{*} \\
(0.00012)\end{array}$ & $\begin{array}{c}.00046^{*} \\
(0.00009)\end{array}$ & $\begin{array}{c}.00032^{*} \\
(0.00005)\end{array}$ & $\begin{array}{c}.00023 * \\
(0.00004)\end{array}$ & $\begin{array}{c}.00014^{*} \\
(0.00003)\end{array}$ & $\begin{array}{l}-0.00001 \\
(0.00001)\end{array}$ \\
\hline s1 & $\begin{array}{c}923.08 * \\
(3.33) \\
\end{array}$ & $\begin{array}{l}958.51 * \\
(10.84)\end{array}$ & $\begin{array}{l}927.76^{*} \\
(10.55) \\
\end{array}$ & $\begin{array}{l}947.21^{*} \\
(10.76)\end{array}$ & $\begin{array}{l}924.75^{*} \\
(11.22)\end{array}$ & $\begin{array}{l}907.18^{*} \\
(10.14)\end{array}$ & $\begin{array}{c}868.54 * \\
(9.49) \\
\end{array}$ & $\begin{array}{c}859.59^{*} \\
(9.02) \\
\end{array}$ & $\begin{array}{c}850.53^{*} \\
(8.76) \\
\end{array}$ & $\begin{array}{c}843.91 * \\
(8.91) \\
\end{array}$ & $\begin{array}{c}828.95^{*} \\
(8.22) \\
\end{array}$ \\
\hline 11 & $-1.04 \mathrm{E}+08$ & $-1.04 \mathrm{E}+07$ & $-1.01 \mathrm{E}+07$ & $-9.50 \mathrm{E}+06$ & $-9.46 \mathrm{E}+06$ & $-9.79 E+06$ & $-1.04 \mathrm{E}+07$ & $-1.07 \mathrm{E}+07$ & $-1.07 \mathrm{E}+07$ & $-1.09 \mathrm{E}+07$ & $-1.10 \mathrm{E}+07$ \\
\hline $\mathrm{N}$ & 136,621 & 14,252 & 13,146 & 13,326 & 12,391 & 12,887 & 13,913 & 13,769 & 14,170 & 14,222 & 14,545 \\
\hline
\end{tabular}




\section{Appendix D: Assessment of Model Goodness-of-fit.}

The purpose of this appendix is to assess the goodness of fit of the estimated utility model. This is done by using the estimated model parameters to predict optimal pre-recession employment and hours of work and then those predictions are compared to the actual observed outcomes.

Figure D1, Panels (a)-(c) compare the actual distribution of annual hours of work (individual and synthetic cell averages) with predicted hours of work at the individual level (Model Prediction), for Husbands (Panel a), Wives (Panel b), and Singles (Panel c). The distribution of predicted hours matches fairly closely the distribution of cell average hours, which serves as the benchmark for the modeling of work hours.

[Figure D1 here]

Table D1 shows that even though the distribution of predicted and actual cell average hours match well, at the mean predicted hours are underestimated. In addition, the average probability of employment is overestimated. The implications of this under- and overestimation can be seen by referring to the equations in Appendix A. Since the prediction of the probability of employment in 2011 is overestimated, the change in the probability given any wage change

(e.g., $\frac{\partial p_{1}}{\partial w_{1}}$ ) is underestimated due to the nonlinearity of the probability cumulative distribution function, and the fact that employment probabilities are in the upper tail of the function. This can be seen in the graphical illustration of Figure D2; for a given change in $\mathrm{Z}$, the change in $\mathrm{P}$ is smaller at higher values of $\mathrm{P}$.

[Figure D2 here]

As can be seen in equations (A3) and (A4) in Appendix A, an understatement in $d p_{j}$ and $p_{j, 2011}^{*}(\mathrm{~J}=1,2)$ will contribute to an understatement of the predicted optimal change in hours. In 
addition, the understatement of optimal predicted hours (among workers) implies that the change in hours is also understated (as the labor supply equations are linear). Both of these results imply that $d h_{1}^{*}$ and $d h_{2}^{*}$ (equations A3 and A4 in Appendix A) are potentially biased toward zero.

This, in turn, implies a potential underestimation of the welfare loss calculated in equations (A5) and (A9). In other words, from a purely goodness-of-fit perspective, the loss in family welfare estimated in this paper should be considered a lower bound. Any estimated welfare gain should also be considered a lower bound. 
Figure D1. Actual (individual and cell averages) and predicted hours of work for those who are working.

\section{Panel (a): Husbands}

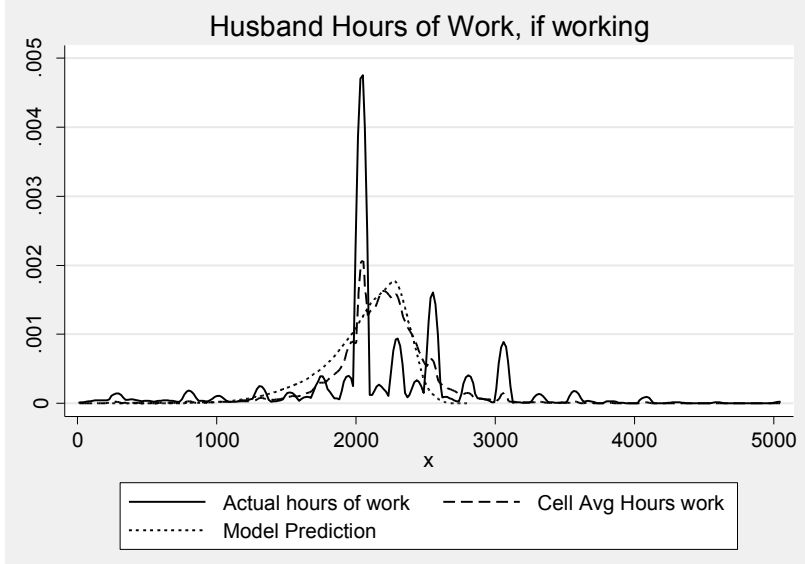

Panel (c): Single Men

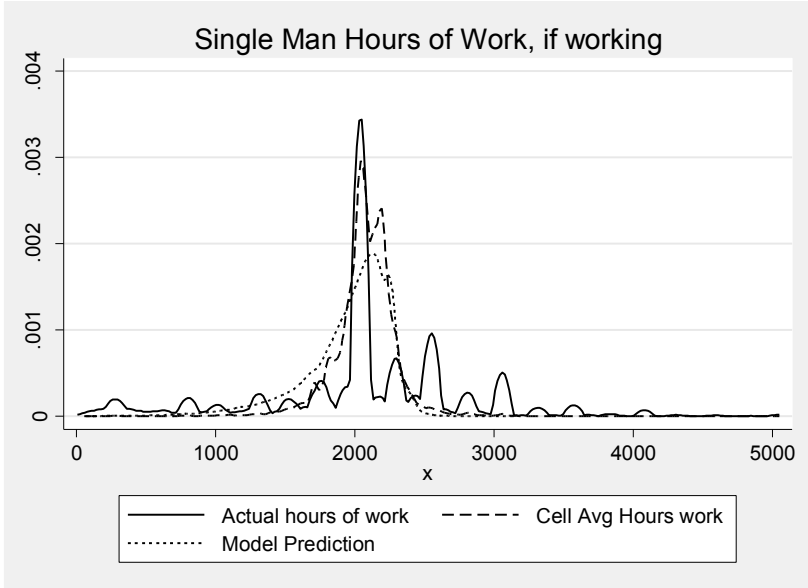

Panel (b): Wives

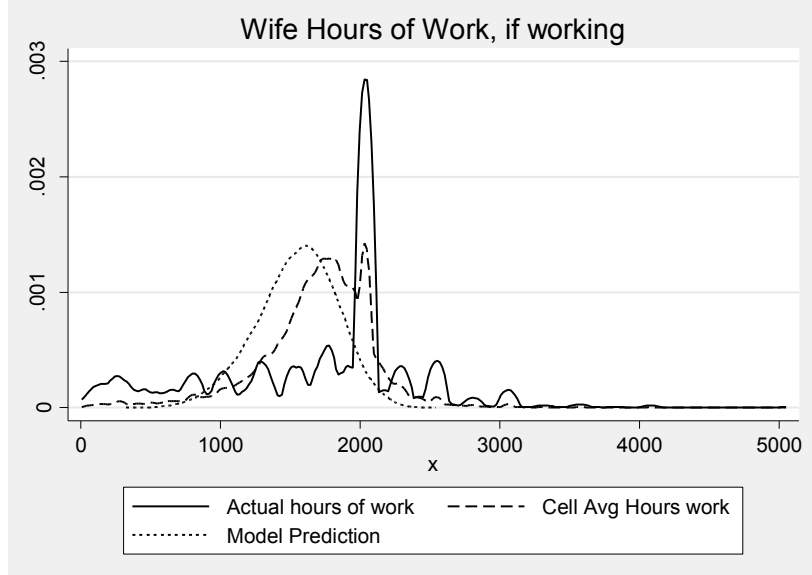

Panel (d): Single Women

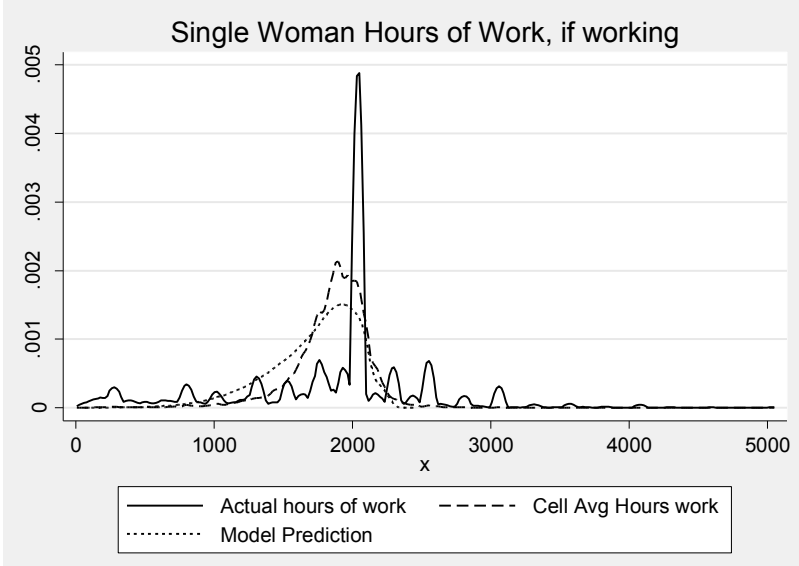


Figure D2. Illustration of how the change in $\mathrm{P}$ is smaller at higher values of $\mathrm{P}$.

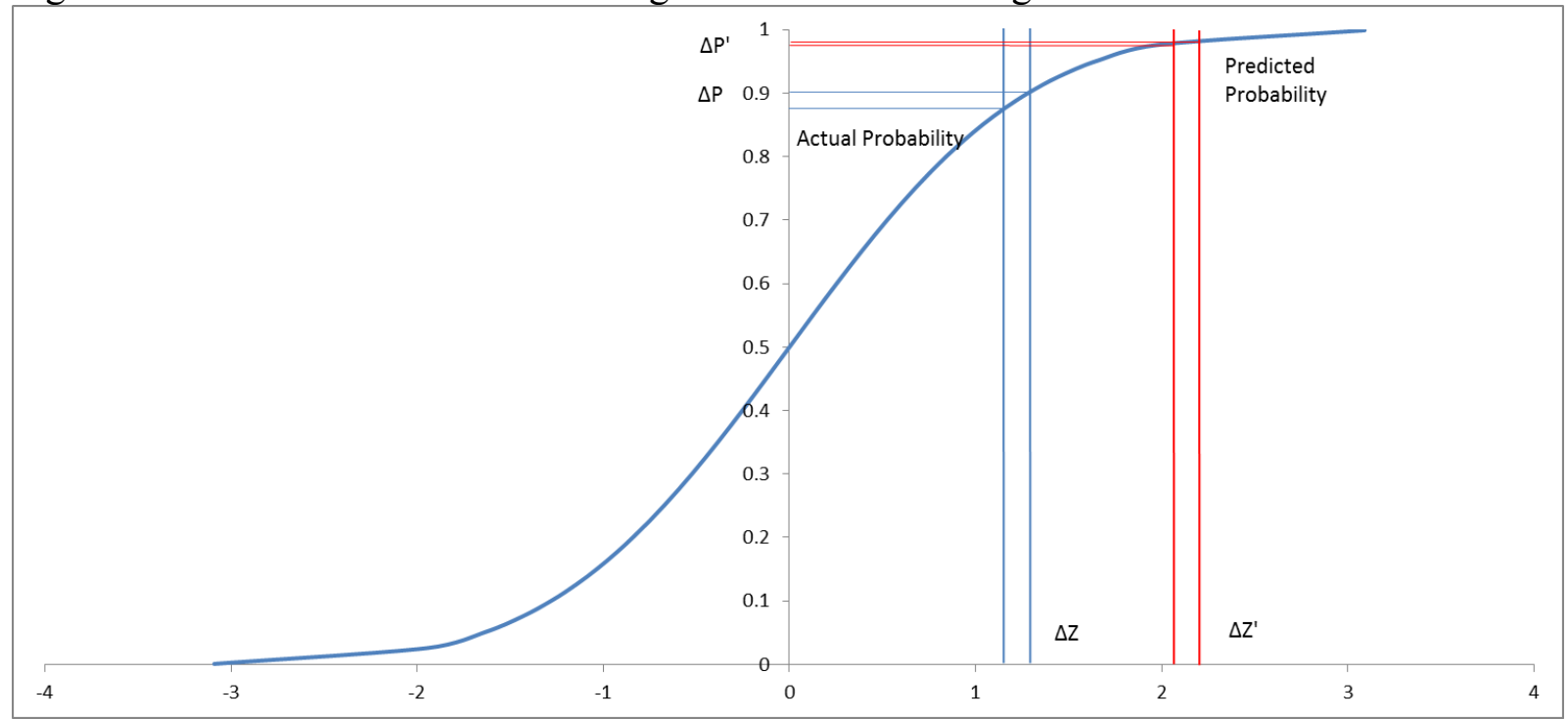

Table D1. Actual and predicted hours (among workers) and employment probabilities.

\begin{tabular}{lcccc}
\hline & \multicolumn{2}{c}{ Married Households } & Single & Single \\
& Husband & Wife & Men & Women \\
\hline Actual Employment Rate & $92.4 \%$ & $75.5 \%$ & $87.1 \%$ & $84.7 \%$ \\
Predicted Employment rate & $98.2 \%$ & $82.6 \%$ & $93.0 \%$ & $92.3 \%$ \\
& & & & \\
Actual Hours work if working & 2197.6 & 1711.8 & 2059.8 & 1855.2 \\
Predicted Hours work & 2076.1 & 1551.4 & 1965.6 & 1742.5 \\
\hline
\end{tabular}

